\title{
Legal framework quality and success of (different types of) venture capital investments
}

\author{
Tereza Tykvováa a,b,* \\ ${ }^{a}$ Chair of Corporate Finance, University of Hohenheim, Wollgrasweg 49, 70599 Stuttgart, Germany \\ ${ }^{\mathrm{b}}$ ZEW Mannheim, L 7, 1, 68161 Mannheim, Germany
}

\section{A R T I C L E I N F O}

\section{Article history:}

Received 17 October 2016

Accepted 24 October 2017

Available online 6 November 2017

\section{JEL classification:}

G24

G32

K4

Keywords:

Venture capital

Legal framework

Success

Internationalization

Syndication

\begin{abstract}
A B S T R A C T
Drawing on an analysis of 8,270 companies from 41 countries, I explore the relationship between success of venture capital investments and legal frameworks in the investment countries. Legal framework quality is related to success, but the effect varies with the deal type. First, the significant and positive relationship between legal framework quality and success is more pronounced for domestic deals than for international deals. Further investigations suggest that international venture capitalists often exit their portfolio companies abroad, particularly when these companies are located in countries with inefficient legal frameworks. In addition, the results lend support to the view that international venture capitalists have a greater experience and reputation. Second, legal framework quality seems to be more important for success in syndicated than in standalone deals. This finding supports the view that a sound legal framework may improve the benefit-cost balance of syndication, while an inefficient legal framework may tend to increase costs in syndicated deals.
\end{abstract}

(c) 2017 Elsevier B.V. All rights reserved.

\section{Introduction}

Research that links legal institutions and finance has been evolving since the 1990s. Studies in this rapidly developing research area have concluded that national differences in legal origins, rules, and law enforcement affect investor protection, capital structure and payout decisions of companies, as well as their performance (e.g., La Porta et al., 1997; 1998; 2000; Klapper and Love, 2002). The consensus is that laws and regulations that reduce the costs of bureaucracy, safeguard property rights, increase the protection of investors, and support the power of courts affect the investment climate positively and encourage the competitiveness of enterprises (for a survey, see Choi, 2002). Many of the earlier works in this field focus on publicly traded companies. In contrast, my analysis concentrates on venture capital investments in private companies. Drawing on global data, I examine the relationship between legal framework quality in the investment countries and success of venture capital investments. While success analysis of worldwide venture capital investments has been a popular research topic in recent years, we know surprisingly little about

\footnotetext{
* Correspondence to: Chair of Corporate Finance, University of Hohenheim, Wollgrasweg 49, 70599 Stuttgart, Germany.

E-mail address: tykvova@uni-hohenheim.de
}

how the relationship between success and legal framework quality varies with the type of the venture capital deal.

My first research question is whether an inefficient legal framework in an investment country harms international venture capitalists (VCs) more or less than their domestic counterparts. The answer is not straightforward a priori because different effects are at play. On the one hand, domestic VCs, that are familiar with country norms and institutions and have closer connections with local authorities, might more easily find ways to mitigate the difficulties resulting from an inefficient legal framework in their home country than VCs coming from abroad, that face the "liability of foreignness" (Zaheer, 1995). On the other hand, international VCs may be harmed less by problems arising from an inefficient legal framework because their portfolio companies will probably be oriented more strongly toward foreign countries than their domestically financed counterparts. For example, portfolio companies backed by international VCs relocate (Cumming et al., 2009) or are exited (Bertoni and Groh, 2014) in a foreign country more often than their peers. Moreover, unlike domestic VCs, international VCs may be experienced and reputable enough to develop effective alternative control mechanisms to cope with an inefficient legal framework (Dai et al., 2012; Chemmanur et al., 2016). Also, VCs coming from countries with better legal frameworks may themselves operate more efficiently than VCs located in countries with an inefficient legal framework because in the latter case, the relationships 
between VCs and their investors will likely be ruled by suboptimal contracts and incur higher costs of bureaucracy (Cumming and Johan, 2006; 2009).

The second research question is how the impact of an inefficient legal framework differs in regard to syndicated and standalone investments. Once more, the expected effect is unclear. Syndication incurs costs that do not exist in standalone investments, because syndicate formation (Cestone et al., 2007) and operation (Wright and Lockett, 2003) may be plagued by information problems and misaligned incentives between participating VCs. VCs close contracts to mitigate these problems (Bachman and Schindele, 2006; Cestone et al., 2007). An inefficient legal framework may give rise to suboptimal contracts, increase the risk that contracts will be broken, lead to delays in the syndication process, and thus raise costs in syndicated investments. In contrast, a superior legal framework may facilitate syndicate relations. Consequently, an inefficient legal framework could have a stronger negative effect on syndicated than standalone deals. However, it is also possible that an inefficient legal framework may have a weaker negative effect on syndicated than standalone deals. This is because different VCs may have complementary know-how and expertise (e.g., Manigart et al., 2006), which could better equip a syndicate than a standalone VC to cope with an inefficient legal framework.

To answer these two questions and to understand which effects prevail, I analyze the success of 8270 venture-backed companies from 41 countries. Following much of the literature on venture capital investment performance (e.g., Hochberg et al., 2007; Sorensen, 2007; Das et al., 2011; Dai et al., 2012; Nahata et al., 2014), I use the exit event to distinguish between successful and unsuccessful investments. Usually, VCs only derive returns when they sell their stakes in companies, because companies do not pay dividends to them during the investment period.

I address the omitted variables problem and a potential selection bias. In all regressions, I control for a multitude of observable VC and country characteristics. To account for unobservable time-invariant industry and country characteristics, I include industry and country dummies. To control for unobservable worldwide developments in time I add time dummies. I am aware of a potential endogeneity of internationalization and syndication. More specifically, I have concerns that international VCs (that tend to be of higher quality) could finance high-quality companies, whose success chances are greater than those of lower-quality companies. This would be consistent with the finding that high-quality companies match with high-quality VCs (e.g., Hsu, 2004). Also, I have concerns that syndicates are likely to have greater selection capabilities (Lerner, 1994; Casamatta and Haritchabalet, 2007) than standalone VCs. I address this issue in the robustness section where I use an instrumental variable approach to account for these problems. To create instruments for international and syndicate VC backing, I use variables that reflect the level of internationalization, resp. syndication of the local VC industry at the time of the particular deal. These variables are highly correlated with the likelihood that the particular deal will be financed by an international VC, resp. by a syndicate. At the same time, these variables are not directly related to the success of a particular deal.

Overall, this study contributes to several strands of literature. First, it extends the literature on law and finance-particularly the literature on how legal factors relate to the performance of venture capital investments. Cumming (2008) and Cumming and Johan (2008) relate different types of contracts to different types of exits. Groh et al. (2010), among others, show that legal framework affects the attractiveness of a country for VC investments. VCs active in countries where the legal framework is inefficient tend to close suboptimal contracts with entrepreneurs (Lerner and Schoar, 2005; Balcarcel et al., 2010), which may negatively affect investment success. In addition, an inefficient legal framework increases the risk of contract repudiation and leads to delays in selection, investment, and exit processes, for example through slow bureaucracies (Cumming et al., 2010). Lerner and Schoar (2005) report that VC investments in countries with inefficient legal frameworks have lower valuations, and Nahata et al. (2014) demonstrates that they turn out to be less successful investments than those in countries with better legal frameworks. Cumming et al. (2006) consistently find that stronger legal institutions are associated with a higher likelihood of an initial public offering (IPO). However, Dai et al. (2012) do not find a clear relation between stronger legal institutions and VC investment success. Although the relationship between legal framework quality and success of VC investments has been studied in several papers, we do not fully understand why different types of deals might be affected differently. To the best of my knowledge, my study is the first to investigate whether legal framework quality relates differently to the performance of international and domestic investments, as well as syndicated and standalone ones, and, if so, in which way.

Related studies use a wide variety of measures as proxies for legal framework quality and these proxies usually do not vary over time. Most studies either use a multitude of historical factors from La Porta et al. $(1997 ; 1998)$ or build an index that combines these factors. More specifically, Balcarcel et al. (2010) use the rule of law, common law, antidirector rights and the one-share-one-vote rule as separate variables, while Lerner and Schoar (2005) rely on legal origin dummies. Cumming et al. (2006) introduce a legality index, which combines six of La Porta et al.'s factors. This index has also been used in later studies (e.g., Dai et al., 2012). Recently, Nahata et al. (2014) constructed an index (and three subindices) from 12 different La Porta et al.'s variables. In contrast to these studies that rely on constant historical variables, I employ a measure-the "legal and regulatory framework" index provided by the IMD World Competitiveness Yearbook-that captures the time-varying quality of the overall legal and regulatory environment in each country. This index covers different aspects of the legal environment and is available on an annual basis for all sample countries. I am convinced that it is advantageous to employ a time-varying measure of legal framework quality because legal changes in several countries have substantially influenced the performance of VC industries in these countries (Armour and Cumming, 2006; Cumming and Knill, 2012).

Second, I contribute to the emerging literature that focuses on VC activity outside the US. Evidence from outside the US is important because other countries have distinctive characteristics and legal frameworks that differ from those prevailing in the US, which may influence the way how VC industry performs. My dataset includes domestic as well as international investments worldwide. Most existing studies that examine the relationship between legal framework quality and success of venture capital investments concentrate on investments from the US only or exclude domestic investments. For example, Nahata et al. (2014) focus on US international investments; Dai et al. (2012) examine international investments in Asia.

This study, third, adds to the literature on internationalization within venture capital industries. The available empirical evidence supports the view that the involvement of international VCs is conducive to success. It attributes this effect to the benefits that international VCs offer their portfolio companies, such as richer experience combined with access to broader networks or to foreign product, capital, and exit markets (Dai et al., 2012; Humphery-Jenner and Suchard, 2013b; Bertoni and Groh, 2014). My study finds another benefit that international VCs bring about: they may mitigate the negative effects that inefficient legal environments in investment countries have on companies' success.

Fourth, my analysis contributes to the literature on VC syndication. Many works investigate benefits associated with syndication 
(e.g., Lerner, 1994; Manigart et al., 2006) and a few works (e.g., Wright and Lockett, 2003) deal with syndication costs. A number of empirical studies lend support to the view that syndication is beneficial to value creation (e.g., Hochberg et al., 2007; Tian, 2012), in particular when international and domestic VCs syndicate (Dai et al., 2012; Humphery-Jenner and Suchard, 2013a; Nahata et al., 2014; Tykvová and Schertler, 2014; Chemmanur et al., 2016). My study adds to this literature by pointing out that syndication benefits and costs relate to the quality of the legal framework in the investment country.

The rest of the paper is organized as follows: in Section 2, I outline the theoretical framework of my study. In Section 3, I describe the dataset, variables, and results obtained from univariate comparisons. Section 4 provides details of the empirical methodology and the results of basic regressions. Sections 5 and 6 address the first and second research questions. Section 7 describes the results of robustness analyses and extensions. Finally, in Section 8, I present a brief summary of the main results and my conclusion.

\section{Related literature and theoretical framework}

\subsection{Legal framework quality and venture capitalist investment success}

Venture capital investments provide a good opportunity to investigate how legal framework quality is related to success and how this relationship differs across different deal types. VCs distinguish themselves from other financial intermediaries mainly through the value they add through active support and monitoring (e.g., Gompers and Lerner, 1999). Governance structures at three different levels, i.e. between VCs and entrepreneurs, among VCs in syndicates, and between VCs and their investors, suffer from conflicts of interest. To align incentives between involved parties VCs enter into complex contracts. The legal framework in a country shapes venture capital contracts at all three levels, which, in turn, affect VCs' willingness to improve the performance of their portfolio companies through active support and monitoring.

A large body of literature examines agency problems that a VC faces vis-à-vis an entrepreneur. These problems result from the information disadvantage that a VC encounters when investing in an entrepreneurial company and from the misalignment between the incentives of the VC and the entrepreneur (e.g., Sahlman, 1990). The VC is exposed to an adverse selection problem, which arises from ex ante unobservable quality because entrepreneurial companies typically lack transparency and track record. The VC also faces a moral hazard problem that results from the unobservable ex post behavior of the entrepreneur.

Because of these potential problems, VCs regulate their relations toward entrepreneurs by means of complex contracts that should align the incentives of both parties. Kaplan and Strömberg (2003) provide an overview of major governance mechanisms in standard VC contracts. They show that VCs use extensive control rights (board rights, voting rights, liquidation rights, conversion rights, anti-dilution rights, and vesting), which are separated from cash-flow rights, and are state contingent. Such contractual provisions should deter low-quality entrepreneurs from entering ex ante. In addition, they aim to induce the entrepreneur to exert effort ex post that should in turn improve company performance (e.g., Metrick and Yasuda, 2011).

Entrepreneurs may be tempted not to comply with contractual provisions if VCs are unable to enforce the contracts effectively. Their ability to enforce them will depend on the efficiency of the legal framework in the investment country. In inefficient legal framework countries, where VCs cannot rely on their ability to enforce the provisions of standard contracts vis-à-vis entrepreneurs, they will tend to employ alternative governance mechanisms.
Lerner and Schoar (2005) show a close relation between legal framework quality in an investment country and VCs' governance mechanisms, such as security type, ownership stake, and various control rights. Their results suggest that in countries with strong legal environments VCs rely on preferred stock equipped with contractually specified control rights, whereas in inefficient legal framework countries they tend to use common stock and debt and to protect their interests via direct control through majority ownership and board dominance. Balcarcel et al. (2010) suggest that international VCs acquire larger stakes in companies that are located in countries with low legal framework quality to protect themselves from the problems that can arise from the inability of courts to enforce contracts involving smaller stakes.

Most empirical studies support the view that alternative corporate governance mechanisms cannot fully compensate for a bad legal framework in an investment country. In addition, such a framework increases the risk of breaches of contract and leads to delays in selection, investment, and exit processes, for example through slow bureaucracies (Cumming et al., 2010). Lerner and Schoar (2005) state that VC transactions in inefficient legal framework countries have lower valuations and returns than those in countries with a stronger legal framework. Nahata et al. (2014) show that in investment countries that promote strong legal rights and effective law enforcement the performance of venture capital investments tends to be better than in investment countries that cannot offer these advantages. These results are consistent with Cumming et al. (2006), who suggest that a high legality index is related to a higher likelihood of a successful IPO in Asia-Pacific countries. However, a related study by Dai et al. (2012) does not support this finding: when the authors control for the characteristics of deal, company, VC and investment country, they show that in most of their models the legality index does not have any significant effect on performance. A possible explanation for these mixed results, on which I shall elaborate later, is that different deal types are affected by the legal framework quality in an investment country to a different degree.

\subsection{Internationalization and legal framework quality}

International VCs might have more difficulty coping with problems that result from a bad legal framework in an investment country than their domestic counterparts. This is because domestic VCs tend to be familiar with local norms and practices. In addition, unlike international VCs, domestic VCs may have close connections within local authorities, which may be helpful in overcoming bureaucratic hurdles, speeding up selection, investment, and exit processes, and solving legal disputes. For all these reasons, it might be easier for domestic VCs to find ways to mitigate the problems arising from an inefficient legal framework.

On the opposite, however, domestic VCs may be harmed more, not less, than international VCs for at least three reasons. First, companies backed by international VCs may be oriented more strongly toward foreign countries than companies backed by domestic VCs, which makes the former less vulnerable toward the domestic legal framework. Cumming et al. (2009) demonstrate that companies backed by international VCs often physically relocate to these VCs' countries. Humphery-Jenner and Suchard (2013b) and Bertoni and Groh (2014) argue that international VCs frequently exit their portfolio companies abroad. The relocation of a company from a country with a bad legal framework to a country with a better one opens the way to superior corporate governance, which, in turn, may improve company competitiveness and performance. Even if the relocation does not happen until the exit and the VC faces agency conflicts and bureaucracy costs for the entire duration of the investment, the prospects of improved corporate governance and higher efficiency would lead to expectations of better 
future performance. These expectations should result in a higher company valuation and thus be reflected in a greater likelihood of a successful exit.

Second, international VCs typically have rich general experience in VC investments and greater reputation than domestic VCs (e.g., Dai et al., 2012; Chemmanur et al., 2016), which may help them in overcoming legal and regulatory hurdles. More expertise and greater reputation may enable international VCs to design and enforce "better" contracts, and thereby to cope more easily with agency conflicts than domestic VCs that may not be experienced enough to develop alternative control mechanisms.

Third, international VCs from countries with better legal frameworks may themselves operate more efficiently due to better contracts and enforcement. This may have a positive effect on their portfolio companies' performance. Adverse selection and moral hazard plague relationships between VCs and their investors. VCs close contracts with their investors to address these problems. In contrast to the abundant literature on contracts between VCs and their portfolio companies, the literature examining contracts between VCs and their investors has been modest since the first analysis by Sahlman (1990). The two main mechanisms that align the interests of VCs and their investors are performance-based compensation via carried interest (e.g., Metrick and Yasuda, 2010) and covenants, which limit reinvesting and also prevent VCs from taking excessive risks or diverting their efforts (e.g., Gompers and Lerner, 1996). Existing cross-country analyses suggest that these mechanisms vary across countries and that they are related to the legal environment. Cumming and Johan (2006) suggest that VCs located in countries with a lower legality index have less incentive to exert effort because they obtain lower carried interest. In addition, Cumming and Johan (2009) investigate how the legality index in a VC's home country relates to the covenants. They report that investors use more covenants in countries with a higher legality index and argue that in these countries investors can benefit more from the covenants since these countries offer more legal certainty. In contrast, in countries with a weaker legal environment, investors face high bureaucracy costs and cannot rely on speedy and effective enforcement of their rights; they therefore use covenants less extensively.

I am not aware of any direct empirical evidence showing how cross-country differences in contracts between VCs and their investors are related to cross-country differences in performance of VC investments. However, I expect that if compensation is more performance sensitive and more covenants are used (which, according to the existing literature, tends to be the case in countries with stronger legal frameworks), VCs may put more effort into selecting, monitoring, and supporting their portfolio companies. This behavior, in turn, may positively affect the success of the portfolio companies. In addition, VCs from strong legal framework countries probably face lower costs of bureaucracy when managing their funds, which again should improve their investment success.

To sum up, the first research question my paper addresses is whether an inefficient legal framework in an investment country is related to the success of international VCs more strongly (because of unfamiliarity and complexity) or less strongly (because of stronger international orientation, greater experience, and better corporate governance within the VC firm) than to the success of domestic VCs.

\subsection{Syndication and legal framework quality}

Extensive literature considers syndication benefits. VCs jointly invest in syndicates, which may help them in reducing idiosyncratic risks (Wilson, 1968; Pichler and Wilhelm, 2001). In addition, ex ante, a syndicate partner will deliver a second opinion on the situation and future prospects of a company during the selection and screening phase (Lerner, 1994; Casamatta and Haritchabalet, 2007). This may help prevent adverse selection and thus increase the quality of the investment. Syndication may also prove beneficial ex post, during the investment phase, because different syndicate members may contribute their unique and potentially complementary skills, knowledge, and experience, as well as access to different networks (Bygrave, 1987; Manigart et al., 2006) that will, in turn, improve performance (Brander et al., 2002; Hochberg et al., 2007; Cumming and Walz, 2010; Tian, 2012).

Apart from these direct benefits, syndication may help in mitigating the agency costs that arise between the early-stage VC and the entrepreneur in staged financing. Fluck et al. (2005) argue that staged financing gives too much bargaining power to the VC that has control over access to financing in future rounds. This can have an adverse effect on company performance because the entrepreneur's stake dilutes and they may exert less effort. In this situation, an early-stage VC that commits to syndication offers the entrepreneur more favorable financing terms and thereby delivers an incentive to exert higher levels of effort. Admati and Pfleiderer (1994) argue that VCs may arrive at a suboptimal continuation decision. Syndication in later stages may be necessary to reach an optimal decision.

Despite these benefits from syndication, many deals are standalone investments. One reason why VCs sometimes do not syndicate their deals is that, compared with standalone investments, they face additional costs in syndicated investments. Ex ante, information problems plague syndicate formation. Cestone et al. (2007) model a two-sided information asymmetry between VCs considering a joint investment in a company. Each VC has a different signal, which is not observable to the other party. Ex post, information problems may negatively affect syndicate operations and a moral hazard problem may arise (Wright and Lockett, 2003). In addition, a VC may expropriate an entrepreneur and the other VCs that invest in a portfolio company by stealing the idea and employing it elsewhere (Bachman and Schindele, 2006; Biais and Perotti, 2008). Even if an obvious theft is unlikely, VCs face a dilution of their competitive advantage in syndicates, which results from the disclosure of a profitable transaction to a competitor (Casamatta and Haritchabalet, 2007). Finally, syndication may cause cooperation problems, reduce flexibility and slow down decision processes (Hopp and Rieder, 2011).

The relationship between syndicate partners is governed by contracts, which-if they can be effectively enforced-can mitigate the problems mentioned earlier and thereby reduce the costs resulting from the syndication. For example, Cestone et al. (2007) develop an appropriate contract design between VCs, whereby VCs truthfully reveal their signals, and Casamatta and Haritchabalet (2007) discuss contracts between VCs that prevent any of them from employing the investment idea elsewhere. In addition, contracts between a VC and an entrepreneur may affect the relationship between VCs in a syndicate and the agency costs of syndication. Bachman and Schindele (2006) suggest a contract between VCs and entrepreneurs that creates incentives for the syndicate partners to monitor each other. Fluck et al. (2005) and Admati and Pfleiderer (1994) derive optimal contracts in staged financing and syndication in later rounds.

Even if I am not aware of any empirical study that deals explicitly with the relation between the legal framework in an investment country and features of syndicate contracts in VC investments, ${ }^{1}$ I assume that an inefficient legal framework will result in suboptimal contracts between VCs and in larger risks of con-

\footnotetext{
${ }^{1}$ Esty and Megginson (2003) describe syndicate structures in project finance and show how they vary in countries with differing creditor rights. In a theoretical study, Pichler and Wilhelm (2001) suggest that a banking syndicate structure can be viewed as an organizational response to agency costs.
} 
tract repudiation, which in turn will increase agency costs within the syndicate. In addition, suboptimal contracts between a VC and an entrepreneur in a country with a bad legal framework may give rise to agency costs within the syndicate. An inefficient legal framework may also delay the syndication process and thus increase syndicate costs. Consequently, a strong legal framework in an investment country should enable syndicates to enhance their net benefits because VCs face lower costs than in countries whose legal framework is less efficient. This view is supported by the findings of Cumming et al. (2010) who suggest that VCs prefer syndicated to standalone deals in countries with a higher legality index, and vice versa. In turn, because syndication generates additional costs and these costs are related to the quality of the legal framework, syndicated deals could be more vulnerable to variations in legal framework quality than standalone deals.

However, one could also argue the opposite namely that syndicates in countries with inefficient legal frameworks should be especially beneficial because different capabilities of different VCs may be important in coping with low-quality laws. If this argument holds true, I should observe a weaker effect of legal framework quality in syndicated than in standalone deals.

To sum up, the second research question I analyze is whether a weak legal framework in an investment country is related to the success of syndicated deals more strongly (due to higher costs) or less strongly (when syndicates are better able to cope with inefficient legal frameworks) than to the success of standalone deals.

\section{Dataset and descriptive statistics}

\subsection{Investment and performance data}

My dataset consists of 8270 companies from 41 countries and covers the period 2000-2013. The sample was extracted from the Bureau van Dijk Zephyr database. Compared with the Thomson VentureXpert database, the most commonly used database in VC research, Zephyr has two advantages for my purposes. First, it has a much better coverage of European deals. Previous works acknowledge that VentureXpert covers US VCs comprehensively (Aizenman and Kendall, 2012). It has also a good coverage of Asian VCs (Dai et al., 2012), at least for recent years, while the data on VCs in other countries is incomplete (Aizenman and Kendall, 2012; Dai et al., 2012). Zephyr started as a database of European mergers and acquisitions (M\&As), but since the second half of the 1990s it has been collecting information on various corporate transactions (M\&As, IPOs, and private equity and venture capital investments) worldwide. This information comes from a variety of sources, such as company press releases, stock exchange announcements and news items (e.g., articles by financial advisers) from relevant websites. Several scholars working in the fields of venture capital and private equity have noticed that the quality of reporting from regions outside Europe improved substantially at the end of the 1990s and started to use Zephyr in recent years (e.g., Beuselinck et al., 2009; Bloom et al., 2009; Michaely and Roberts, 2012; Schertler and Tykvová, 2012). To account for the fact that Zephyr data during the 1990s may strongly over-represent European countries, I chose the year 2000 as my starting point. The second advantage Zephyr exhibits is that the investment data is directly linked to exit data (M\&As and IPOs) as well as company data (database Orbis) via unique company identifiers.

The sample period (2000-2013) is divided into three subperiods. I employ the first three years of data (January 2000-December 2002) to generate VC-related variables. The investment sample covers investments made in the period January 2003-December
$2008 .^{2}$ To identify which of these investments had been successfully exited, I extracted data on worldwide M\&As and IPOs until March 2013.

The dependent variable successful exit is binary, with 1 denoting a successful exit (M\&As and IPOs) and 0 denoting an unsuccessful exit. ${ }^{3}$ If a company was not successfully exited by March 2013 and a further investment round had not been recorded between January 2009 and March 2013 in Zephyr, I label this company an "unsuccessful exit" and set my dependent variable to 0 . I believe this is a sufficiently long period in which a potential new investment round or an exit would take place. Such approach is common in the literature because commercial databases, which rely on information provided by market participants, underreport bankruptcies. For example, Nahata (2008) uses an investment sample ending in 2001 and classifies all companies that had not exited successfully by the beginning of 2006 as unsuccessful exits. Hochberg et al. (2007) assume that a company for which they do not find any information about exit at the fund's tenth anniversary has been liquidated. I deal with this issue also in the robustness section in alternative ways.

In Table 1, I categorize venture capital investments on the basis of the investment country, and I distinguish between successful and unsuccessful exits. Each company represents one observation. In the case of multiple investment rounds in one company, main variables and controls are calculated at the first investment round. Most investments were made in developed countries, and $45.8 \%$ of the companies that obtained venture capital were based in the US. UK, France, Germany, and Canada together represented $33.0 \%$ of the sample. In total, $26.0 \%$ were successfully exited. This percentage is within the range reported by previous studies (which deal with other countries and other time periods): Nahata (2008) reports $33.5 \%$ and Nahata et al. (2014) come up with $24.2 \%$.

\subsection{Variables and descriptive statistics}

To proxy for legal framework quality I employ the "legal and regulatory framework" index, one of the more than 300 variables that are provided on an annual basis for 61 countries by the IMD World Competitiveness Yearbook. In general, the IMD World Competitiveness Yearbook aims at assessing and comparing the ability of countries to create an appropriate level playing field for companies operating in these countries across different dimensions. Some variables are based on hard data and other variables rely on opinion surveys among business executives in top and middle management. The variable "legal and regulatory framework" index that I use in this study is based on an opinion survey. In this survey, managers are asked whether the legal and regulatory framework encourages the competitiveness of enterprises in their country. The answer can take a value on a scale between 0 and 10 .

This index thus captures a broad variety of different aspects of a country's legal framework. Nahata et al. (2014) argue that (p. 1061) "composite legal indices better and more fully capture the disparate components of law" and are therefore more useful than indices capturing only single elements. Furthermore, "legal and regulatory framework" index provided by the IMD World Competitiveness Yearbook fulfills one important criterion: it varies over time and thus reflects that legal framework quality may have changed

\footnotetext{
2 The basis is the sample from Tykvová and Schertler (2014).

${ }^{3}$ It is common to classify successful exit as either IPO or M\&A (trade sale), see e.g., Hochberg et al. (2007); Dai et al. (2012); Nahata (2008); Nahata et al. (2014). Hochberg et al. (2007) also show that this measure is a meaningful proxy for VC returns. Nevertheless, I use alternative success definitions (considering buybacks and secondary sales) as a robustness check, but the main messages remain unaltered. I also analyze IPOs and trade sales separately (such as, e.g., Giot and Schwienbacher, 2007), but I do not find large differences in the effects of international VCs and syndication.
} 
Table 1

Companies and exits by investment country.

\begin{tabular}{|c|c|c|c|c|c|c|}
\hline Investment country & Companies & Success & Failure & Success rate & Legal framework & $\ldots$ and its rel. std. dev. \\
\hline AUSTRALIA & 147 & 71 & 76 & $48.3 \%$ & 6.69 & 0.079 \\
\hline AUSTRIA & 46 & 13 & 33 & $28.3 \%$ & 6.17 & 0.102 \\
\hline BELGIUM & 120 & 35 & 85 & $29.2 \%$ & 3.76 & 0.155 \\
\hline BRAZIL & 9 & 1 & 8 & $11.1 \%$ & 2.96 & 0.155 \\
\hline BULGARIA & 5 & 2 & 3 & $40.0 \%$ & 3.88 & 0.059 \\
\hline CANADA & 447 & 111 & 336 & $24.8 \%$ & 6.45 & 0.096 \\
\hline CHILE & 1 & 0 & 1 & $0.0 \%$ & 6.04 & 0.158 \\
\hline CHINA & 47 & 4 & 43 & $8.5 \%$ & 5.55 & 0.117 \\
\hline CZECH REPUBLIC & 3 & 1 & 2 & $33.3 \%$ & 3.85 & 0.121 \\
\hline DENMARK & 84 & 19 & 65 & $22.6 \%$ & 6.90 & 0.013 \\
\hline ESTONIA & 2 & 0 & 2 & $0.0 \%$ & 6.48 & 0.061 \\
\hline FINLAND & 106 & 26 & 80 & $24.5 \%$ & 6.59 & 0.149 \\
\hline FRANCE & 689 & 194 & 495 & $28.2 \%$ & 3.47 & 0.168 \\
\hline GERMANY & 425 & 80 & 345 & $18.8 \%$ & 3.66 & 0.136 \\
\hline GREECE & 5 & 0 & 5 & $0.0 \%$ & 3.46 & 0.165 \\
\hline HONGKONG & 3 & 1 & 2 & $33.3 \%$ & 7.92 & 0.053 \\
\hline HUNGARY & 7 & 0 & 7 & $0.0 \%$ & 5.17 & 0.137 \\
\hline INDIA & 63 & 1 & 62 & $1.6 \%$ & 4.83 & 0.085 \\
\hline IRELAND & 72 & 19 & 53 & $26.4 \%$ & 6.10 & 0.061 \\
\hline ISRAEL & 13 & 4 & 9 & $30.8 \%$ & 5.78 & 0.031 \\
\hline ITALY & 115 & 30 & 85 & $26.1 \%$ & 2.98 & 0.173 \\
\hline JAPAN & 31 & 4 & 27 & $12.9 \%$ & 4.39 & 0.111 \\
\hline LITHUANIA & 5 & 2 & 3 & $40.0 \%$ & 3.63 & 0.028 \\
\hline LUXEMBOURG & 6 & 2 & 4 & $33.3 \%$ & 5.87 & 0.136 \\
\hline MALAYSIA & 6 & 0 & 6 & $0.0 \%$ & 6.40 & 0.101 \\
\hline NETHERLANDS & 148 & 31 & 117 & $20.9 \%$ & 5.50 & 0.141 \\
\hline NEW ZEALAND & 5 & 1 & 4 & $20.0 \%$ & 5.58 & 0.106 \\
\hline NORWAY & 75 & 38 & 37 & $50.7 \%$ & 5.63 & 0.102 \\
\hline PHILIPPINES & 1 & 0 & 1 & $0.0 \%$ & 3.49 & 0.101 \\
\hline POLAND & 12 & 6 & 6 & $50.0 \%$ & 2.61 & 0.109 \\
\hline PORTUGAL & 14 & 6 & 8 & $42.9 \%$ & 3.62 & 0.074 \\
\hline RUSSIAN FEDERATION & 24 & 11 & 13 & $45.8 \%$ & 2.91 & 0.168 \\
\hline SINGAPORE & 17 & 5 & 12 & $29.4 \%$ & 8.25 & 0.051 \\
\hline SOUTH AFRICA & 10 & 2 & 8 & $20.0 \%$ & 4.91 & 0.170 \\
\hline SPAIN & 269 & 34 & 235 & $12.6 \%$ & 4.43 & 0.209 \\
\hline SWEDEN & 247 & 60 & 187 & $24.3 \%$ & 5.40 & 0.157 \\
\hline SWITZERLAND & 31 & 0 & 31 & $0.0 \%$ & 6.38 & 0.083 \\
\hline THAILAND & 3 & 0 & 3 & $0.0 \%$ & 4.63 & 0.206 \\
\hline UKRAINE & 1 & 0 & 1 & $0.0 \%$ & 2.43 & 0.148 \\
\hline UNITED KINGDOM & 1166 & 303 & 863 & $26.0 \%$ & 4.65 & 0.165 \\
\hline UNITED STATES & 3790 & 1036 & 2754 & $27.3 \%$ & 5.97 & 0.094 \\
\hline Total & 8270 & 2153 & 6117 & $26.0 \%$ & 5.01 & 0.115 \\
\hline
\end{tabular}

This table shows the country composition of my sample, which covers 8270 companies. It includes investments that were made between January 1, 2003, and December 31, 2008, and their exits that took place by March 31, 2013. The data were drawn from the Zephyr database and IMD World Competitiveness Yearbook.

substantially over time. This is an important issue because changes in legal framework quality have substantially influenced the performance of VC industries (e.g., Armour and Cumming, 2006; Cumming and Knill, 2012). This index has been used in prior studies, but not in the VC context yet. For example, Blind (2012) studies the relationship between this index and innovations in OECD countries. Blind (2012) and Nicoletti and Prior (2007) argue that opinions of industry representatives and objective indicators capture the same underlying reality.

The "legal and regulatory framework" index (variable legal framework) is correlated to time-invariant indicators used in prior studies on international VC investments. The correlation with Nahata et al. (2014) composite legal measure is 57\%, the correlation with Cumming et al. (2006) legality index is $39 \%{ }^{4}$

An important advantage of the legal framework variable is a good availability-it covers all sample countries and all years. Table 1 shows the mean value of the legal framework variable and the relative standard deviation over the sample years by countries (on the basis of six annual observations per country between 2003 and 2008). The average ranges from 2.43 in Ukraine (the lowest

\footnotetext{
4 The correlation between these two measures is $42 \%$
}

value amounted to 1.69 in 2008) to 8.25 in Singapore (the highest value was 8.65 in 2007 and 2008). The index varies in time and this variation is not concentrated in less developed countries. The standard deviation over the mean ranges between 0.013 in Denmark and 0.209 in Spain. On average, the relative standard deviation amounts to 0.115 (0.112 in developed countries and to 0.120 in developing countries).

Table 2, panel A, depicts the mean and median values over the whole sample, which are 5.32 and 5.54 . This table suggests that a better legal framework is positively related to success; the legal framework is on average significantly higher for investments that were successfully exited.

Table 2, panel B, gives an overview of the deal types and their representation in subsamples of successful and unsuccessful exits. Internationalization is captured by the binary variable inter. This variable equals 1 if there is at least one international VC financing the investment and 0 otherwise. International investments account for $30.58 \%$ of the sample. The binary variable synd, which equals 1 if more than one VC finances the investment and 0 otherwise, reflects syndication. In slightly less than half the sample investments (49.14\%), VCs formed a syndicate. In order to analyze the patterns of internationalization and syndication in a more fine- 
Table 2

Descriptive statistics.

\begin{tabular}{|c|c|c|c|c|c|c|c|c|c|}
\hline \multicolumn{10}{|c|}{ Panel A: Legal framework (company sample) } \\
\hline \multicolumn{2}{|l|}{ Variable } & \multicolumn{2}{|c|}{ Mean (median) } & Std. dev. & Min & Max & Successful exit $=0$ & Successful exit $=1$ & Wilcoxon test \\
\hline \multicolumn{2}{|c|}{ Legal framework } & \multicolumn{2}{|c|}{$5.32(5.54)$} & 1.16 & 1.69 & 8.65 & 5.27 & 5.48 & $-8.45^{* * *}$ \\
\hline \multicolumn{10}{|c|}{ Panel B: Investment type (company sample) } \\
\hline & \multicolumn{2}{|c|}{ Fraction } & \multicolumn{2}{|c|}{ Success rate } & & \multicolumn{2}{|c|}{ Successful exit $=0$} & Successful exit = 1 & Wilcoxon test \\
\hline inter & \multicolumn{2}{|c|}{$30.58 \%$} & \multicolumn{2}{|c|}{$30.49 \%$} & & \multicolumn{2}{|c|}{$28.83 \%$} & $35.48 \%$ & $-5.77^{* * *}$ \\
\hline synd & \multicolumn{2}{|c|}{$49.14 \%$} & \multicolumn{2}{|c|}{$28.86 \%$} & & \multicolumn{2}{|c|}{$47.42 \%$} & $53.98 \%$ & $-5.26^{* * *}$ \\
\hline$D$ & \multicolumn{2}{|c|}{$37.62 \%$} & \multicolumn{2}{|c|}{$21.09 \%$} & & \multicolumn{2}{|c|}{$40.27 \%$} & $30.19 \%$ & $8.33^{* * *}$ \\
\hline$D-D$ & \multicolumn{2}{|c|}{$31.80 \%$} & \multicolumn{2}{|c|}{$28.37 \%$} & & \multicolumn{2}{|c|}{$30.90 \%$} & $34.33 \%$ & $-2.95^{* * *}$ \\
\hline$I-D$ & \multicolumn{2}{|c|}{$15.10 \%$} & \multicolumn{2}{|c|}{$31.22 \%$} & & \multicolumn{2}{|c|}{$14.09 \%$} & $17.95 \%$ & $-4.31^{* * *}$ \\
\hline$I$ & \multicolumn{2}{|c|}{$13.24 \%$} & \multicolumn{2}{|c|}{$31.42 \%$} & & \multicolumn{2}{|c|}{$12.32 \%$} & $15.83 \%$ & $-4.15^{* * *}$ \\
\hline$I-I$ & \multicolumn{2}{|c|}{$2.24 \%$} & $.00 \%$ & & & & & $1.70 \%$ & $1.96^{* *}$ \\
\hline Total & $100 \%$ & & $5.03 \%$ & & & 10 & & $100 \%$ & \\
\hline Panel C: & chara & eristics (dya & sample) & & & & & & \\
\hline & & Mean $(\mathrm{m}$ & dian) & Std. dev. & Min & $\operatorname{Max}$ & Successful exit $=0$ & Successful exit $=1$ & Wilcoxon test \\
\hline VC reputa & & $0.04(0)$ & & 0.11 & 0 & 1 & 0.04 & 0.05 & $-11.00^{* * *}$ \\
\hline VC conne & dness & $0.41(0)$ & & 0.49 & 0 & 1 & 0.40 & 0.46 & $-7.60^{* * *}$ \\
\hline$V C$ exper & & $22.71(7)$ & & 46.57 & 0 & 554 & 20.73 & 28.88 & $-12.61^{* * *}$ \\
\hline VC exper & & $15.32(5)$ & & 26.40 & 0 & 211 & 14.40 & 18.11 & $-11.62^{* * *}$ \\
\hline Panel D: & untry & laracteristic & (company & y sample) & & & & & \\
\hline & Mean & median) & Std. dev. & Min & & & Successful exit $=0$ & Successful exit $=1$ & Wilcoxon test \\
\hline growth & 2.65 & .80) & 1.00 & -0.40 & & & 2.62 & 2.74 & $-8.64^{* * *}$ \\
\hline GDPcap & 40,66 & $(42,003)$ & 8885.14 & 561.50 & & 920.00 & $40,808.10$ & $40,253.57$ & $8.63^{* * *}$ \\
\hline return & 6.89 & .77) & 28.36 & -73.83 & & & 5.04 & 12.14 & $-10.08^{* * *}$ \\
\hline mcap & 1.26( & 37) & 0.34 & 0.09 & & & 1.27 & 1.25 & $4.85^{* * * *}$ \\
\hline VC size & 1.29( & 26) & 0.61 & 0.00 & & & 1.30 & 1.25 & $3.61^{* * *}$ \\
\hline
\end{tabular}

This table presents descriptive statistics of the included variables. All variables and their sources are described in the appendix. Investments were made between January 1, 2003, and December 31, 2008, and exits took place by March 31, 2013. The Wilcoxon test is the z-value of the two-sample Wilcoxon rank-sum (Mann-Whitney) test. It is used to test the hypothesis that the two samples are derived from populations with the same distribution. ${ }^{*} p<.10,{ }^{* *} p<.05,{ }^{* * *} p<.01$.

grained manner, I define five deal types: a standalone domestic investment $(D)$, a syndicated domestic investment $(D-D)$, a crossborder investment syndicated between international and domestic VCs $(I-D)$, a standalone cross-border investment $(I)$, and a crossborder investment syndicated between international VCs $(I-I)$. In the entire sample, $37.62 \%$ are standalone domestic investments and $31.80 \%$ are undertaken by a syndicate of domestic VCs. In $15.10 \%$ of all investments, international VCs syndicate with domestic partners. Finally, $13.24 \%$ of the sample are standalone cross-border investments and only $2.24 \%$ are syndicated among international VCs. Internationalization and syndication seem to be beneficial to success. International deals are successful in $30.49 \%$ and syndicated deals in $28.86 \%$ of cases, which is higher than the average success rate of $26.03 \%$. Among the five deal types, $I$ and $I-D$ deals reach the highest success rates of $31.42 \%$ and $31.22 \%$.

Table 2, panel C, captures VC characteristics and how they are related to success. In this panel, I use a sample comprising dyads between companies and VCs. The dyad sample is larger than the company sample, because each syndicated investment is treated as a set of several observations (their number equals the number of syndicate members), whereas in the company sample it is treated as a single observation. I construct proxies for VC reputation (VC reputation) using the fraction of past IPO exits (Nahata, 2008), and VC connectedness (VC connectedness) using past syndicate relationships (Hochberg et al., 2007). I further consider VC general experience (VC exper), which I measure as a past deal count (Sorensen, 2007; Demiroglu and James, 2010; Dai et al., 2012), and VC experience in the investment country (VC exper cou) using a past deal count in the country concerned (Dai et al., 2012). To generate these four variables, I employ a 3 -year rolling window. ${ }^{5}$ In the regressions, I log transform the experience-related variables because they are skewed. The univariate tests suggest that reputation, connectedness, general and country-specific experience are positively related to success.

I also employ country-specific characteristics, which include country growth prospects, economic development, stock market return, liquidity of the financial markets and the size of the local VC industry (Table 2, panel D).

\section{Empirical methodology and basic specifications}

\subsection{Empirical methodology}

To investigate how legal framework quality, internationalization, and syndication relate to the likelihood of a successful exit, I employ logit regressions with the dependent variable successful exit as my basic specifications. To answer the first research question as

\footnotetext{
5 Nahata (2008) and Hochberg et al. (2007) construct their variables "VC reputation" and "VC connectedness" on a rolling basis as well. As for the experience variable, most researchers use the cumulative number of investments as proxy for VC experience. For example, Sorensen (2007) employs the cumulative number of investment rounds since 1975. My approach deviates from Sorensen because the data for investments before 2000 are not accurate. Moreover, I believe that using a rolling window makes sense for my purposes because VC experience may evolve over time, due to changes in management team composition. Moreover, regulatory frameworks and market situations alter over time, which is especially relevant when looking at VC experience in a specific investment country. Demiroglu and James (2010) follow a similar approach and employ a proxy for experience that is based on the number of deals completed in the previous 3 years.
} 
to whether the legal framework quality in an investment country is related to the success of international VCs more or less strongly than to the success of domestic VCs, I interact the variable legal framework with the variable inter or, alternatively, the variable I (Section 5). To explore the second research question as to whether the link between legal framework quality and investment success differs between syndicated and standalone investments, I interact the variable legal framework with the variable synd (Section 6). In all regressions, I control for the VC characteristics and the country characteristics described in Section 3. For the VC characteristics in syndicated deals, I use the average across all VCs in a syndicate. I also control for the presence of a corporate VC or a bank-based VC with dummies CVC and BVC. Moreover, I add country dummies to account for all time-invariant country-specific features, which may be related to other regressors and to success, such as cultural conditions (e.g., Cumming et al., 2014; Nahata et al., 2014). I also include industry dummies to incorporate differences in success rates across different industries. Finally, I employ time dummies to account for worldwide changes in economic conditions. ${ }^{6}$

\subsection{Basic specifications}

Before I analyze the two research questions, I establish the basic relationship between success and legal framework quality, internationalization, and syndication for all deal types in Table 3, columns 1-4.

The results reveal that a better legal framework, syndication, and internationalization go hand in hand with a higher likelihood of successful exits. A 1-standard deviation increase in the variable legal framework from its mean increases the likelihood that a company realizes a successful exit by 5.8 percentage points (columns 1-3). The results in column 3 suggests that, compared with standalone domestic deals (the reference category), the likelihood of success is higher in syndicated domestic deals (4 percentage points), standalone cross-border deals (10 percentage points), and deals syndicated between international and domestic VCs (6 percentage points). ${ }^{7}$ The results from the dyad sample (column 4) confirm the positive effects of sound legal framework in the PC country (but not the VC country), syndication, and internationalization on success.

As to the control variables, reputation and connectedness are closely related to investment success. VC experience is only significant when I exclude variables that capture internationalization. Finally, most country-specific effects are insignificant. Only stock market returns seem to fuel successful exits.

\section{International versus domestic deals}

In this section, I address my first research question and explore how the relationship between legal framework quality and investment success differs for deals with and without the participation of international VCs. Table 3, columns 5 and 6 , depicts the results. Column 5 corresponds to the basic specification 1 and adds an interaction term between legal framework and the binary variable inter. In column 6 , which corresponds to column 3 , I employ a fine-grained distinction of deal types and I interact legal framework with the binary variable $I$.

Columns 5 and 6 are non-linear (logit) models. Computing marginal effects of an interaction term in a non-linear model is

\footnotetext{
${ }^{6}$ As logit model estimates with many fixed effects are only consistent under strict assumptions, I run OLS models as a robustness check and obtain similar results.

${ }^{7}$ Following Cumming et al. (2016), I compare the effects of international VCs on M\&As and IPOs. Consistently with their results, I find a more pronounced effect of international VCs on IPOs than on M\&As; however, the difference is not significant.
}

more complicated than establishing an interaction effect in linear models. I use the approach developed by Norton et al., (2004). They suggest computing the cross-partial derivative of the expected value of the dependent variable to establish the marginal effect value. Moreover, to assess the statistical significance, the value of the cross-partial derivative must be calculated (but not that of the interaction term). Both interaction terms legal frameworkXinter and legal frameworkXI have negative effects, which are statistically significant. ${ }^{8}$ These results support the view that international VCs have a lower exposure to the legal framework in an investment country than their domestic counterparts.

I offered three potential reasons for this difference. The first one was that companies backed by international VCs have a stronger orientation toward foreign countries. To look into this issue, for exited companies, I collect information about the exit country. More specifically, for M\&As, I track whether a foreign or a domestic acquirer buys the portfolio company. For IPOs, I look at which stock exchange the company goes public. In general, I expect companies to exit abroad more often when the company is backed by an international VC and when the legal framework in the investment country is weak. If my conjecture that a stronger foreign orientation may be a way in which international VCs help companies mitigate the effects of bad legal frameworks is correct, then I should find that companies from bad legal framework countries exit more often abroad when they are backed by international than by domestic investors.

To analyze this issue, I explore the relationship between the likelihood of a non-local exit (a binary dependent variable that equals 1 for successful exits outside the investment country and 0 for successful exits within the investment country) and the presence of international VCs, legal framework quality in the investment country, and their interaction. In these regressions, it is important to control for other factors that may be related to the nonlocal exit and the legal framework quality, such as the size of local M\&A and IPO markets. ${ }^{9}$ The size of the local M\&A market (overall and high-tech) and the size of the local IPO market (overall and high-tech) are positively and significantly correlated to the legal framework quality.

I present the results in Table 4. When I control for the size of the high-tech M\&A and IPO market (column 1) or for the size of the overall M\&A and IPO market (column 4), legal framework and its interaction with the variable inter remain significant which leads to the conclusion that companies backed by international VCs exit more often abroad and this effect is more pronounced in countries with weak legal frameworks.

I further analyze whether international VCs may help companies in exiting abroad when local M\&A and IPO markets are weak. For this purpose, in further specifications of Table 4 I interact each of the four local market variables with the variable inter (one by one). Both M\&A interaction terms are statistically significant and negative, supporting the view that for companies from countries with weak local acquisition markets (overall and high-tech), international VCs may be beneficial in finding non-local acquirers. I do not find a similar effect for IPOs. This may be due to the fact that M\&As represent the main exit channel in my sample.

A second potential reason for the observed differences could be that international VCs tend to be more experienced and more reputable than domestic VCs, and will therefore be more likely to find alternative ways of implementing their rights in countries with inferior legal frameworks. Table 5, panel A shows that mean (median) experience of all VCs involved in the deal is 46.34 (15.57)

\footnotetext{
8 To measure internationalization, I alternatively use the number of countries involved (e.g., Cumming et al., 2016). This variable has a positive marginal effect and its interaction with the variable legal framework has a negative effect.

${ }^{9}$ I thank an anonymous referee for making me aware of this point.
} 
Table 3

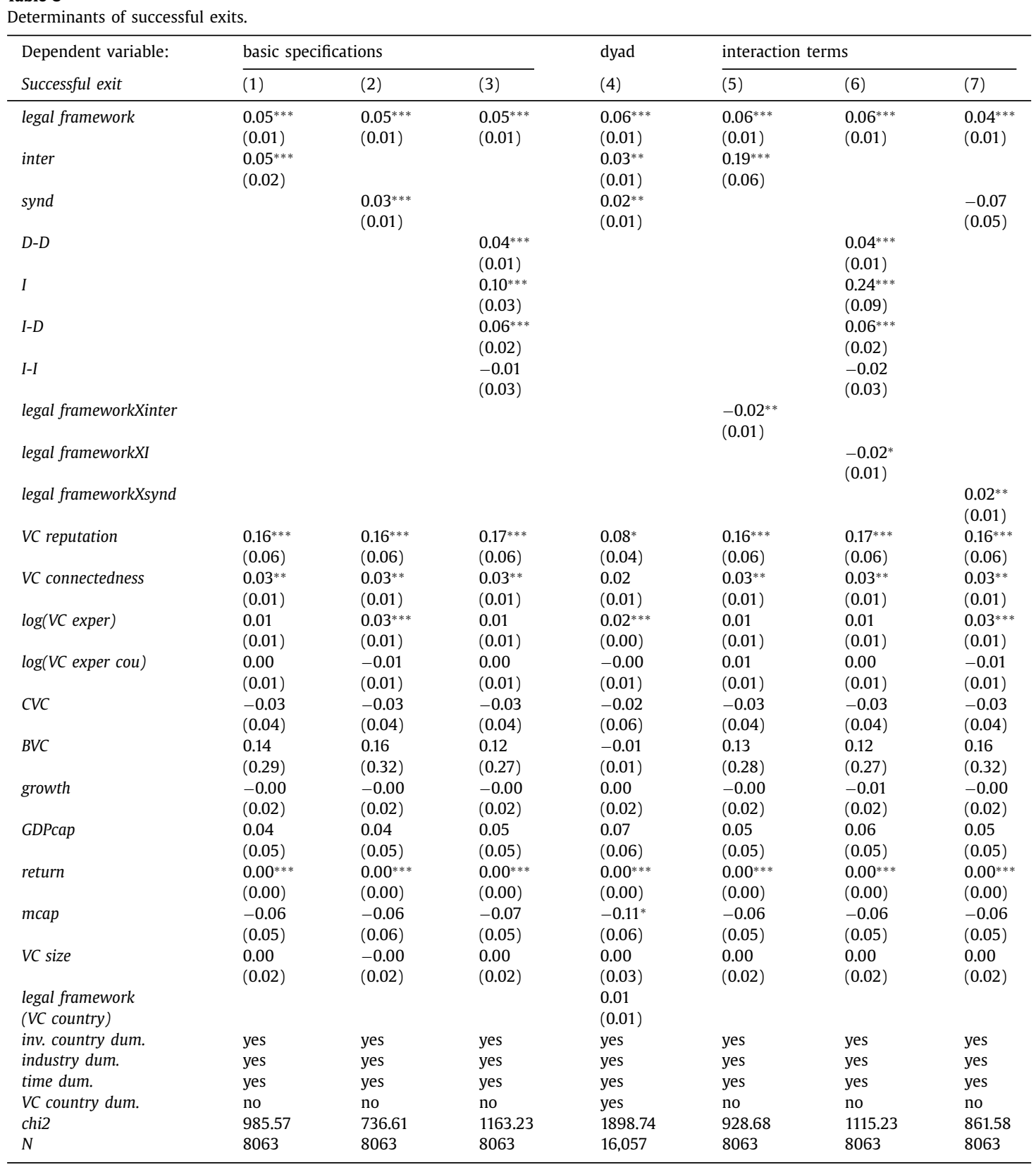

The table depicts the marginal effects from logit models with successful exit as the dependent variable. Investments were made between January 1, 2003, and December 31, 2008, and exits took place by March 31, 2013. Columns 1-3 and 5-7 use the company sample and column 4 employs the dyad sample. All variables and their sources are described in the appendix. The macroeconomic variables are from the VC investment year. The standard errors (clustered by investment country and year; see Petersen 2009) appear in brackets. ${ }^{*} p<.10$, ${ }^{* *} p<.05,{ }^{* * *} p<.01$.

in international deals and 18.31 (7.00) in domestic deals. The difference in mean (median) experience between international and domestic deals is highly statistically significant. International deals also involve more reputable VCs than domestic deals. Mean (median) reputation of VCs in international deals amounts to 0.06 (0.03) compared to $0.04(0.00)$ in domestic deals and the differences are statistically significant (see panel B).

As further checks (results not depicted), I re-run the regression from Table 3, column 5 with alternative interaction terms. I include either legal framework $X$ VC exper or legal framework X VC reputation, but both interaction terms are insignificant. I conclude that international VCs provide value added that is grounded somewhere else than only in their experience or reputation. I also analyze whether international VCs with a greater experience and greater reputation are more successful in mitigating the negative impacts of bad legal frameworks than those with a lower experience and lower reputation. To this aim, I construct triple interaction terms (legal framework $X$ inter $X$ VC exper; legal framework $X$ inter $X V C$ reputation) and include them in the main regression, but they turn insignificant.

Third, I suggested that international VCs might be less vulnerable to an inferior legal framework in an investment country because their relationships with their own investors might be affected by the legal framework quality in the VC's home country rather than the investment country. Successful exit and legal framework quality in the VC country are positively correlated. However, when I control for other effects in a multivariate setting, I do not find support for the conjecture that the legal framework 
Table 4

Determinants of non-local exits.

\begin{tabular}{|c|c|c|c|c|c|c|}
\hline $\begin{array}{l}\text { Dependent variable: } \\
\text { Non-local exit }\end{array}$ & (1) & $(2)$ & (3) & (4) & (5) & (6) \\
\hline legal framework & $\begin{array}{l}-0.04^{* *} \\
(0.02)\end{array}$ & $\begin{array}{l}-0.02 \\
(0.02)\end{array}$ & $\begin{array}{l}-0.13 \\
(0.09)\end{array}$ & $\begin{array}{l}-0.04^{* *} \\
(0.02)\end{array}$ & $\begin{array}{l}-0.03 \\
(0.02)\end{array}$ & $\begin{array}{l}-0.03^{*} \\
(0.02)\end{array}$ \\
\hline inter & $\begin{array}{l}0.27^{* * *} \\
(0.11)\end{array}$ & $\begin{array}{l}0.11^{* * * *} \\
(0.03)\end{array}$ & $\begin{array}{l}0.62^{* * *} \\
(0.20)\end{array}$ & $\begin{array}{l}0.25^{* *} \\
(0.11)\end{array}$ & $\begin{array}{l}0.11^{* * * *} \\
(0.04)\end{array}$ & $\begin{array}{l}0.10^{* * *} \\
(0.04)\end{array}$ \\
\hline legal frameworkXinter & $\begin{array}{l}-0.03^{*} \\
(0.02)\end{array}$ & & & $\begin{array}{l}-0.03^{*} \\
(0.02)\end{array}$ & & \\
\hline MA_hightech & $\begin{array}{l}0.09 \\
(0.16)\end{array}$ & $\begin{array}{l}0.11 \\
(0.16)\end{array}$ & $\begin{array}{l}0.36 \\
(0.91)\end{array}$ & & & \\
\hline MA_hightechXinter & & $\begin{array}{l}-0.07^{*} \\
(0.04)\end{array}$ & & & & \\
\hline IPO_hightech & $\begin{array}{l}0.32 \\
(1.06)\end{array}$ & $\begin{array}{l}0.34 \\
(1.06)\end{array}$ & $\begin{array}{l}4.97 \\
(6.09)\end{array}$ & & & \\
\hline IPO_hightechXinter & & & $\begin{array}{l}-6.81 \\
(4.60)\end{array}$ & & & \\
\hline MA_all & & & & $\begin{array}{l}0.02 \\
(0.03)\end{array}$ & $\begin{array}{l}0.03 \\
(0.03)\end{array}$ & $\begin{array}{l}0.02 \\
(0.03)\end{array}$ \\
\hline MA_allXinter & & & & & $\begin{array}{l}-0.02^{*} \\
(0.01)\end{array}$ & \\
\hline IPO_all & & & & $\begin{array}{l}0.14 \\
(0.23)\end{array}$ & $\begin{array}{l}0.16 \\
(0.23)\end{array}$ & $\begin{array}{l}0.22 \\
(0.24)\end{array}$ \\
\hline IPO_allXinter & & & & & & $\begin{array}{l}-0.13 \\
(0.18)\end{array}$ \\
\hline synd & $\begin{array}{l}0.06^{* *} \\
(0.02)\end{array}$ & $\begin{array}{l}0.06^{* *} \\
(0.02)\end{array}$ & $\begin{array}{l}0.32^{* *} \\
(0.13)\end{array}$ & $\begin{array}{l}0.06^{* *} \\
(0.02)\end{array}$ & $\begin{array}{l}0.06^{* *} \\
(0.02)\end{array}$ & $\begin{array}{l}0.06^{* *} \\
(0.02)\end{array}$ \\
\hline VC reputation & $\begin{array}{l}-0.33^{* * *} \\
(0.12)\end{array}$ & $\begin{array}{l}-0.33^{* * *} \\
(0.12)\end{array}$ & $\begin{array}{l}-1.83^{* * *} \\
(0.68)\end{array}$ & $\begin{array}{l}-0.34^{* * *} \\
(0.12)\end{array}$ & $\begin{array}{l}-0.33^{* * *} \\
(0.12)\end{array}$ & $\begin{array}{l}-0.33^{* * *} \\
(0.12)\end{array}$ \\
\hline VC connectedness & $\begin{array}{l}0.06^{* * * *} \\
(0.02)\end{array}$ & $\begin{array}{l}0.06^{* * *} \\
(0.02)\end{array}$ & $\begin{array}{l}0.34^{* * *} \\
(0.13)\end{array}$ & $\begin{array}{l}0.07^{* * *} \\
(0.02)\end{array}$ & $\begin{array}{l}0.06^{* * * *} \\
(0.02)\end{array}$ & $\begin{array}{l}0.06^{* * * *} \\
(0.02)\end{array}$ \\
\hline $\log (V C$ exper $)$ & $\begin{array}{l}-0.00^{*} \\
(0.00)\end{array}$ & $\begin{array}{l}-0.00 \\
(0.00)\end{array}$ & $\begin{array}{l}-0.00 \\
(0.00)\end{array}$ & $\begin{array}{l}-0.00^{*} \\
(0.00)\end{array}$ & $\begin{array}{l}-0.00 \\
(0.00)\end{array}$ & $\begin{array}{l}-0.00 \\
(0.00)\end{array}$ \\
\hline $\log ($ VC exper cou $)$ & $\begin{array}{l}0.00 \\
(0.00)\end{array}$ & $\begin{array}{l}-0.00 \\
(0.00)\end{array}$ & $\begin{array}{l}-0.00 \\
(0.00)\end{array}$ & $\begin{array}{l}0.00 \\
(0.00)\end{array}$ & $\begin{array}{l}-0.00 \\
(0.00)\end{array}$ & $\begin{array}{l}0.00 \\
(0.00)\end{array}$ \\
\hline growth & $\begin{array}{l}-0.00 \\
(0.04)\end{array}$ & $\begin{array}{l}-0.00 \\
(0.04)\end{array}$ & $\begin{array}{l}-0.01 \\
(0.19)\end{array}$ & $\begin{array}{l}-0.00 \\
(0.04)\end{array}$ & $\begin{array}{l}0.00 \\
(0.04)\end{array}$ & $\begin{array}{l}0.00 \\
(0.04)\end{array}$ \\
\hline GDPcap & $\begin{array}{l}0.08 \\
(0.07)\end{array}$ & $\begin{array}{l}0.08 \\
(0.07)\end{array}$ & $\begin{array}{l}0.42 \\
(0.40)\end{array}$ & $\begin{array}{l}0.08 \\
(0.08)\end{array}$ & $\begin{array}{l}0.08 \\
(0.08)\end{array}$ & $\begin{array}{l}0.08 \\
(0.08)\end{array}$ \\
\hline return & $\begin{array}{l}-0.00 \\
(0.00)\end{array}$ & $\begin{array}{l}-0.00 \\
(0.00)\end{array}$ & $\begin{array}{l}-0.00 \\
(0.00)\end{array}$ & $\begin{array}{l}-0.00 \\
(0.00)\end{array}$ & $\begin{array}{l}-0.00 \\
(0.00)\end{array}$ & $\begin{array}{l}-0.00 \\
(0.00)\end{array}$ \\
\hline mcap & $\begin{array}{l}-0.09 \\
(0.07)\end{array}$ & $\begin{array}{l}-0.09 \\
(0.07)\end{array}$ & $\begin{array}{l}-0.49 \\
(0.41)\end{array}$ & $\begin{array}{l}-0.13 \\
(0.09)\end{array}$ & $\begin{array}{l}-0.14 \\
(0.09)\end{array}$ & $\begin{array}{l}-0.14^{*} \\
(0.09)\end{array}$ \\
\hline VC size & $\begin{array}{l}0.04 \\
(0.04)\end{array}$ & $\begin{array}{l}0.04 \\
(0.04)\end{array}$ & $\begin{array}{l}0.21 \\
(0.21)\end{array}$ & $\begin{array}{l}0.04 \\
(0.04)\end{array}$ & $\begin{array}{l}0.04 \\
(0.04)\end{array}$ & $\begin{array}{l}0.04 \\
(0.04)\end{array}$ \\
\hline inv. country dum. & yes & yes & yes & yes & yes & yes \\
\hline industry dum. & yes & yes & yes & yes & yes & yes \\
\hline time dum. & yes & yes & yes & yes & yes & yes \\
\hline chi2 & 305.15 & 304.39 & 303.83 & 306.37 & 330.02 & 303.79 \\
\hline$N$ & 1913 & 1913 & 1913 & 1913 & 1913 & 1913 \\
\hline
\end{tabular}

The table depicts the marginal effects from logit models with non-local exit as the dependent variable. Investments were made between January 1, 2003, and December 31, 2008, and exits took place by March 31, 2013. All variables and their sources are described in the appendix. The macroeconomic variables are from the VC investment year. The standard errors appear in brackets. ${ }^{*} p<.10,{ }^{* *} p<.05,{ }^{* * *} p<.01$.

quality in the VC home country positively affects the likelihood of a successful exit. In Table 3, column 4 the marginal effect of $l e-$ gal framework (VC country) is not statistically significant. A possible explanation is that VCs usually come from countries with sound legal frameworks. Consequently the variation in the legal framework variable across VC countries is much lower than across investment countries. The variable turns significant when I remove country dummies.

To sum up, the results support the view that international VCs have a lower exposure to the legal framework in an investment country than their domestic counterparts. A possible explanation is that companies backed by international VCs are more strongly oriented toward foreign countries. This is reflected, for example, in a higher likelihood of a non-local exit, particularly for companies coming from countries with inefficient legal frameworks. These countries usually also suffer from a lack of local buyers and international VCs may help in finding buyers abroad.

\section{Syndicated versus standalone deals}

To answer my second research question, how the relationship between legal framework quality and success differs in syndicated and standalone deals, I interact legal framework with synd and run a logit regression on successful exit (column 7 in Table 3). The interaction term has a positive marginal effect, which is statistically significant. This result supports the view that legal framework quality matters more in syndicated than in standalone deals. In an average legal framework country, syndicates increase the likelihood of a successful exit by 5.1 percentage points compared to standalone investments. When the legal framework variable increases by 1-standard deviation above its mean, the positive syndicate effect increases to 7.2 percentage points.

These findings support the conjecture that syndicates can better develop their benefits in countries with favorable legal regimes. Bad legal frameworks tend to give rise to extra costs in syndicated investments that do not exist in standalone investments. Thus, the 
Table 5

Experience and reputation in domestic and international deals.

\begin{tabular}{llllll}
\hline \multicolumn{7}{l}{ Panel A: VC exper } & \multicolumn{3}{l}{ Min } & Max \\
\hline \multicolumn{7}{c}{ Mean } & Median & Std. dev. & Min & \\
\hline inter $=1$ & 46.34 & 15.57 & 78.97 & 0 & 554 \\
inter $=0$ & 18.31 & 7.00 & 36.45 & 0 & 554 \\
difference test & $-22.09^{* * *}$ & $-16.88^{* * *}$ & & & \\
Panel B: VC reputation & & & & \\
\hline \multicolumn{7}{c}{ Mean } & Median & Std. dev. & Min & Max \\
\hline inter $=1$ & 0.06 & 0.03 & 0.10 & 0 & 1 \\
inter $=0$ & 0.04 & 0.00 & 0.10 & 0 & 1 \\
difference test & $-9.62^{* * *}$ & $-22.92^{* * *}$ & & & \\
\hline
\end{tabular}

The table presents descriptive statistics of $V C$ exper and VC reputation in international and domestic investments. Investments were made between January 1, 2003, and December 31, 2008. All variables and their sources are described in the appendix. The difference tests are either the $t$-value of the $t$-test below the means or the z-value of the two-sample Wilcoxon rank-sum (Mann-Whitney test) below the medians. ${ }^{*} p<.10$, ${ }^{* *} p<.05,{ }^{* * *} p<.01$.

findings do not support the alternative view that syndicates could better cope with costs that arise from an inefficient legal framework than standalone VCs.

\section{Robustness analyses and extensions}

\subsection{Alternative proxies for legal framework quality}

I check whether my findings on how the relationship between legal framework and success of venture capital investments varies across different deal types are robust to alternative proxies for legal framework quality. I employ the proxies that Nahata et al., (2014) constructed from LaPorta et al. (1997 and 1998) variables. I use the composite measure (legal_NHT) as well as its three subindices for shareholder rights (shareholder_NHT), enforcement rights (enforcement_NHT) and accounting standards (account_NHT) and interact each of them with the internationalization and syndication variables. I run the same regressions as in Table 3, columns $5-7$, but employ these alternative proxies instead of the legal framework variable. I also exclude country dummies since these alternative proxies do not vary over time.

I present the results with the composite measure legal_NHT and its interaction in Table 6, panel A, columns 1-3. I then analyze whether one part of the legal framework matters more than the others. In the remaining columns (4-6) of panel A, I include the three subindices instead of the composite measure and interact shareholder_NHT with the type dummies. In panel B, I employ interaction terms with enforcement_NHT and account_NHT.

The results with the composite measure in panel A (columns 1-3) are a bit weaker than the results in the main analysis (in Table 3), but remain consistent. This makes me confident that my main results are not driven by the choice of the legal framework variable. The findings from the remaining regressions (columns 46 in panel A; columns 1-6 in panel B) support the view that shareholder rights matter most, which is in line with findings by Nahata et al. (2014).

\subsection{Measures from different rounds}

In the next check, I employ RHS variables (i.e., the deal type indicators and all control variables) from the last round instead of the first round. Since uncertainty and risk evolve over time and are higher in the first than in the last round, internationalization and syndication may have different effects in different rounds. The results, which I present in Table 7 , are a bit weaker, but qualitatively similar to the main results. I also check whether there are different effects of internationalization and syndication in first and follow-on rounds by employing a triple interaction term that combines the interaction terms from the main analysis with an indicator for a first/follow-on round (results not reported). The triple interaction terms turn insignificant (with one exception, which is only significant at the $10 \%$ level).

\subsection{Endogeneity}

Even with the bunch of control variables included, the endogeneity problem may still persist. Unobserved company characteristics, such as quality, may be related to the investment type and to the successful exit. In particular, international VCs could pick higher-quality companies that have a higher success chances than their peers. Also, syndicates might have superior selection capabilities (Lerner 1994; Casamatta and Haritchabalet, 2007) than standalone investors and be thus involved in higher-quality companies.

To address this issue, I employ an instrumental variable (IV) approach. To create an instrument for international VC backing, I use int_share, which is the share of international on total deals in the same country and year (excluding the particular deal). I expect this variable to be positively correlated with the likelihood that a particular deal in the respective country and year will be backed by an international VC. At the same time, I assume that int_share is not directly related to the success of a particular deal. I use a similar procedure to create an instrument for syndication. I apply synd_share, which is the share of syndicated on total deals in the same country and year (excluding the particular deal).

When implementing this IV approach, I face two main challenges. First, my endogenous variables inter and synd are binary. Second, they appear on their own and also in interaction terms. To account for the first problem, I rely on the approach suggested in Wooldridge (2010). I first estimate a reduced form probit regression for inter using all exogenous variables plus int_share. I then calculate the fitted probability from this regression, which I use as an instrument for inter in the second stage regression. I employ the same approach for synd with synd_share instead of int_share.

To deal with the second problem, I have to create a second instrument for the respective interaction term (legal framework with inter and legal framework with synd) to estimate the respective second stage regression. I employ the interaction between the fitted probability from the respective first stage probit regression and the legal framework variable.

The results from the first stage regressions confirm that the variables int_share, resp. synd_share are relevant instruments. They are positively correlated with the likelihood that a particular deal in the respective country and year is backed by an international VC, resp. a syndicate. The results from second stage regressions are shown in Table 8 , which presents the same models as Table 3 (columns $1-3,5-7$ ), but includes one (columns 1-3) or two (columns 4-6) instruments. The results confirm the findings from the main analysis.

I have to acknowledge that variables based on country averages may be problematic instruments. On the one hand, they satisfy the relevance condition, but this at the same time implies that common country-level heterogeneity is correlated with the respective endogenous variable. But, if a model has such unobserved countrylevel heterogeneity, the exclusion restriction will not be satisfied. Therefore, endogeneity may still be a concern.

\subsection{Censoring}

Next, I deal with potential right censoring, which may be a concern with the kind of data I use. In the main analysis, I stopped my investment sample in 2008 to alleviate this concern. As a robustness check, I exclude investments in the two last investment 
Table 6

Alternative measures of legal framework.

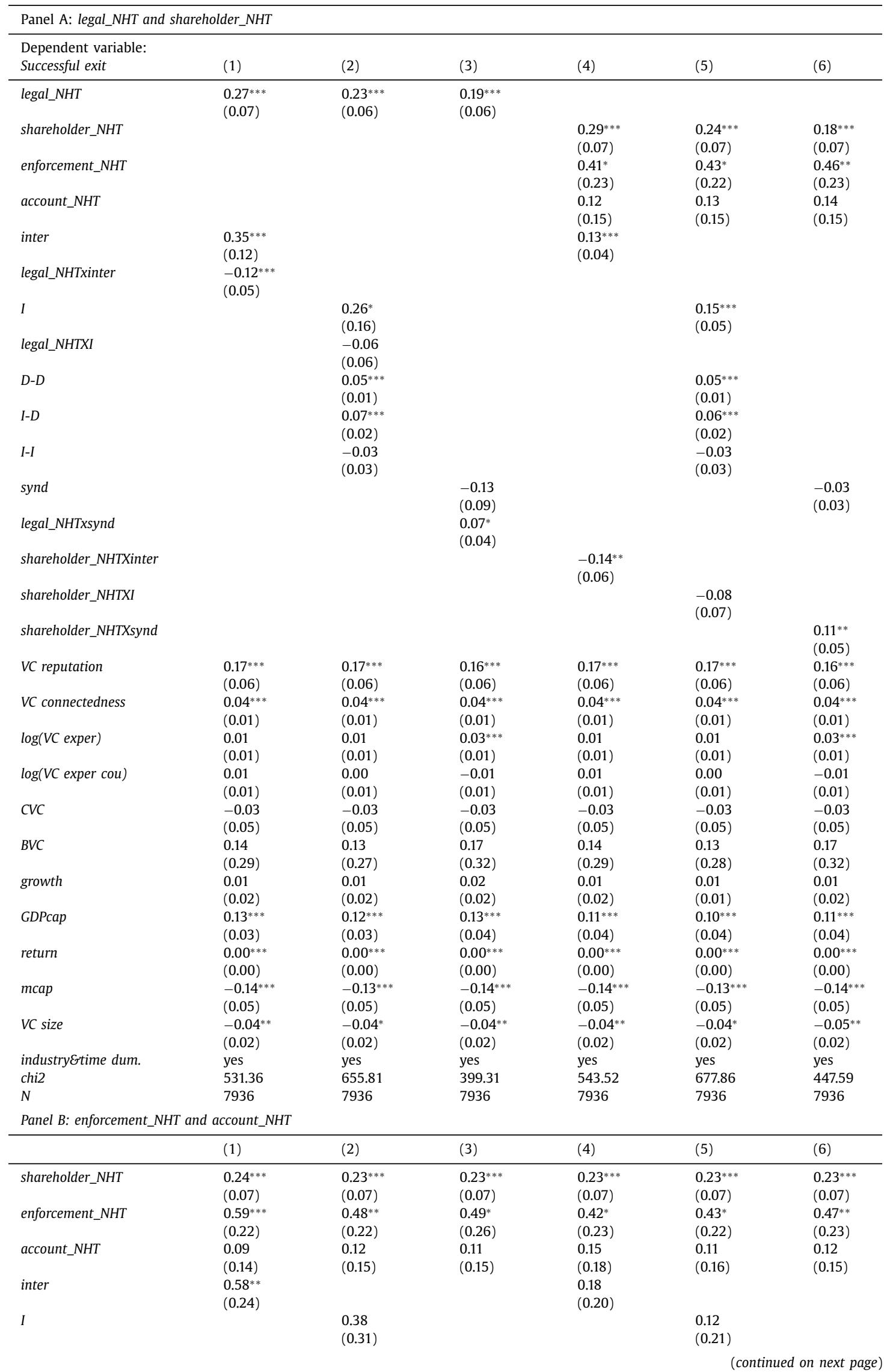


Table 6 (continued)

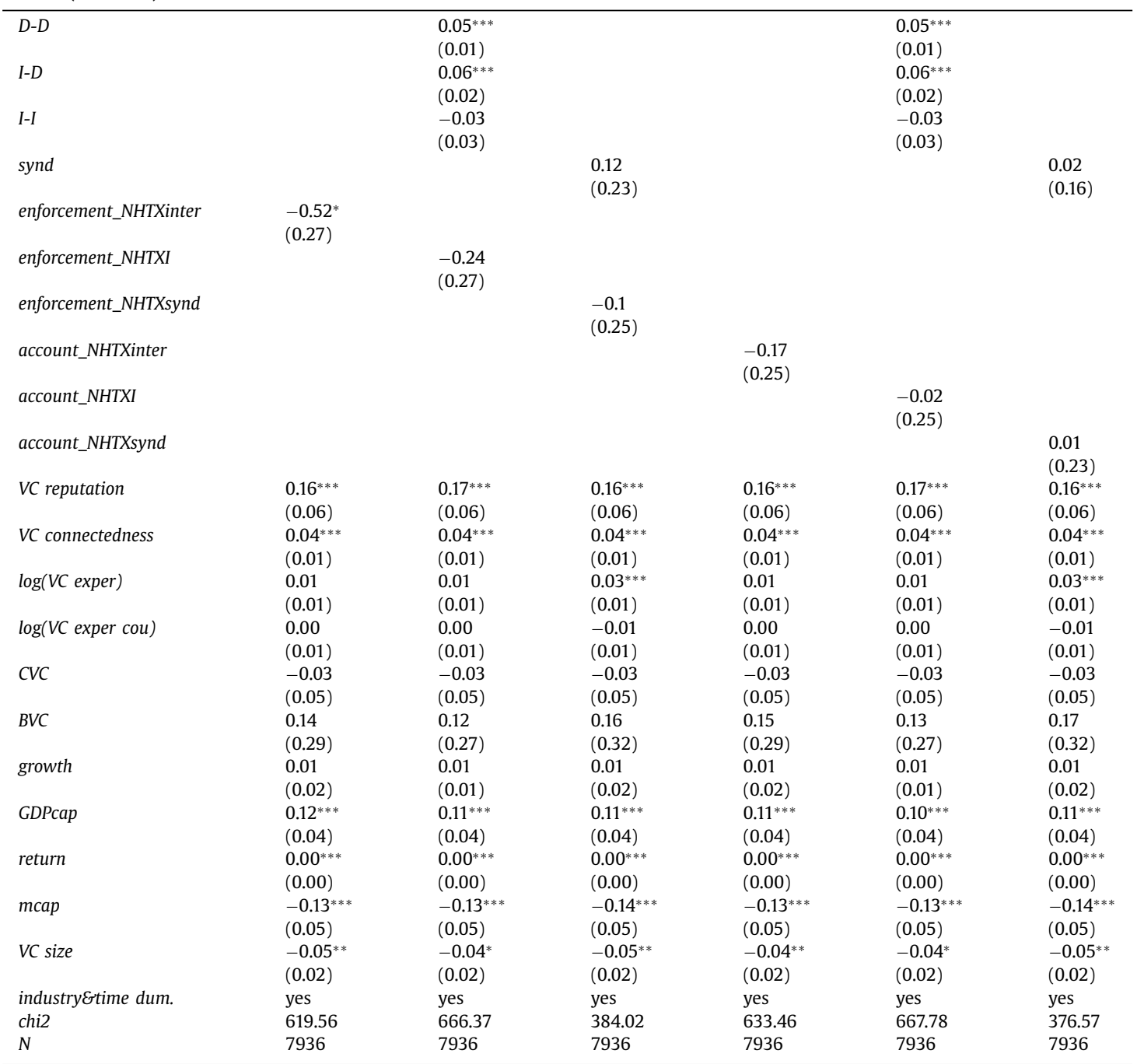

The table depicts the marginal effects from logit models with successful exit as the dependent variable. Investments were made between January 1, 2003, and December 31, 2008, and exits took place by March 31, 2013. All variables and their sources are described in the appendix. The macroeconomic variables are from the VC investment year. The standard errors (clustered by investment country and year; see Petersen 2009) appear in brackets. ${ }^{*} p<.10,{ }^{* *} p<.05,{ }^{* * *} p<.01$.

years (2007 and 2008) from my analysis, while I still consider exits till March 2013. For this check, I re-run the regressions from Table 3 within a restricted sample of companies with a first VC investment between 2003 and 2006. The marginal effect of the interaction term between legal framework and inter (as well as legal framework and I) remains negative, while the marginal effect of the interaction terms between legal framework and synd (as well as legal framework and $D-D$ ) stays positive. Their magnitudes are similar. They are statistically significant, albeit at lower levels.

Alternatively, I run hazard rate models, which have been used in a similar context (e.g., Giot and Schwienbacher 2007, Hochberg et al., 2007; Nahata, 2008) and which explicitly control for right censoring. I employ a Cox model (e.g., Nahata, 2008) and again use the same right-hand side variables as in Table $3 .{ }^{10}$ The results are shown in Table 9, columns 1-3. They confirm the findings from the logit models. The legal framework effect is positive, suggesting that the hazard rate increases and, consequently, the expected time to exit decreases with a better legal framework. Internationalization has a positive effect, while syndication is insignificant as a stan-

\footnotetext{
10 The results are similar with an accelerated-time-to-failure (ACT) model with time-to-exit lognormally distributed (as in Hochberg et al., 2007).
}

dalone variable. All interaction terms have their expected signs and are statistically significant. These findings thus support the prior conclusions that legal framework quality matters less in international than in domestic deals (columns 1-2) and more in syndicated than in standalone deals (column 3). These results confirm that the right censoring problem does not drive the results from my main analyses.

\subsection{Regional differences}

I deal also with regional differences. One concern is that US VCs, which represent the largest proportion of VCs in my sample and which are more experienced, more reputable, and have larger networks on average than VCs from other sample countries, may bias the results. To examine the potential "US effect," I run my regressions for a sample that excludes VCs located in the US. Moreover, I conduct the same analyses without US companies, which represent the largest proportion of companies in my sample. The results stay qualitatively similar. In the next step, I repeat these analyses while excluding companies and VCs from the country with the second largest number of VC investments in my sam- 
Table 7

RHS variables from the last round.

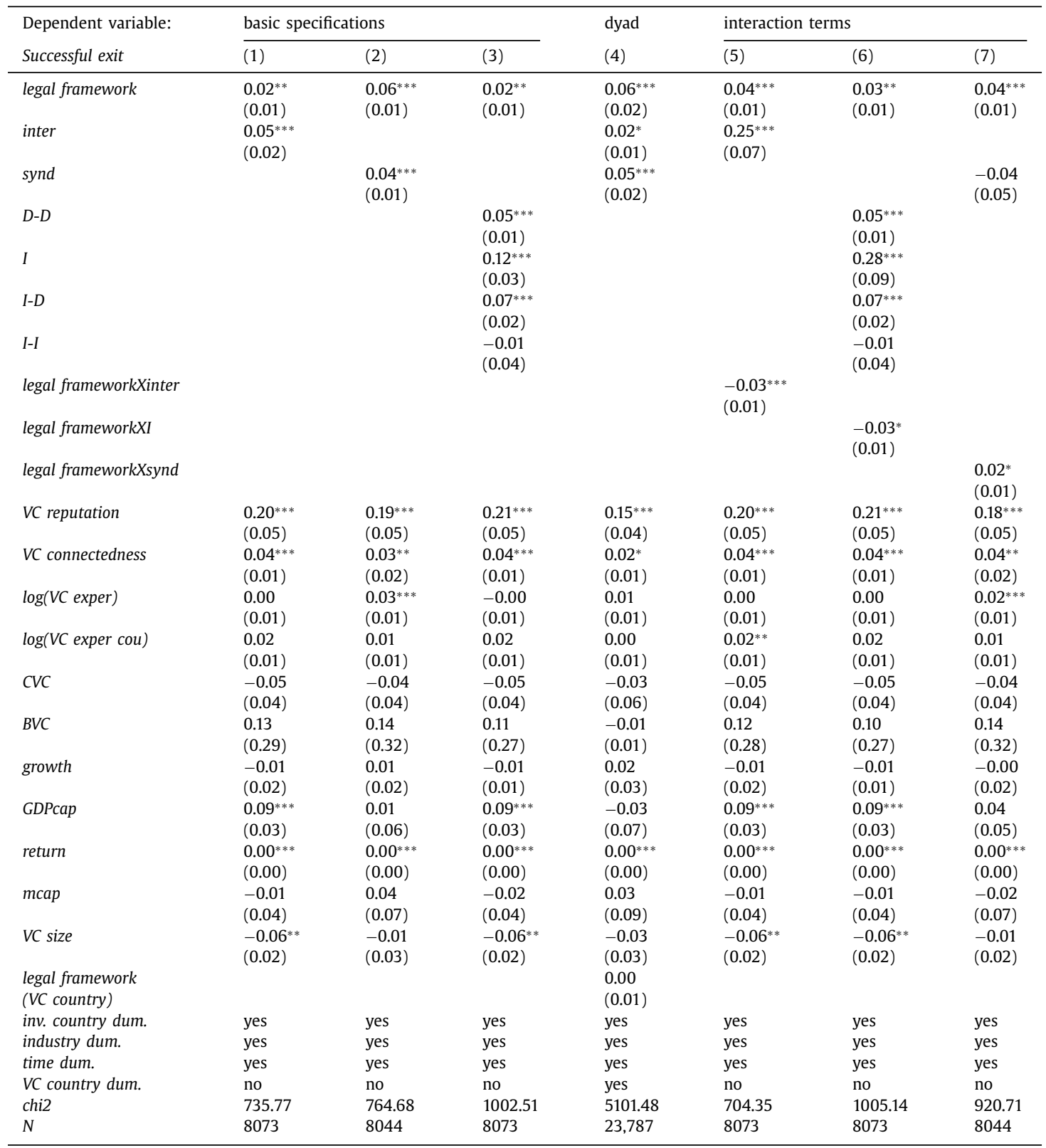

The table depicts the marginal effects from logit models with successful exit as the dependent variable. Investments were made between January 1, 2003, and December 31, 2008, and exits took place by March 31, 2013. All variables and their sources are described in the appendix. The macroeconomic variables are from the VC investment year. The standard errors (clustered by investment country and year; see Petersen 2009) appear in brackets. ${ }^{*} p<.10,{ }^{* *} p<.05,{ }^{* * *} p<.01$.

ple, the UK. Again, the findings remain unaltered. Thus, my main results are not driven by VCs or companies from the US or the UK.

Finally, I exclude countries that did not receive investments in at least 15 companies (as in Nahata et al., 2014) to mitigate the concerns that outliers may affect the results. I conclude that the results are not driven by these observations.

\subsection{Alternative measures of success}

Finally, I want to test whether my results are robust toward an alternative measure of success based on company characteristics. I check which company characteristics are available at an annual basis from Orbis for my sample companies. Unfortunately, company characteristics are reported in Orbis only for a subset of sam- ple companies and years and the availability of different variables varies substantially. For my analysis, I choose the "number of employees", which is the variable with the best availability. However, even with this variable, I lose approximately $60 \%$ of observations. Table 9, columns 4-6 depicts the results of the main regressions (with interaction terms) from Table 3 with (log) number of employees as the dependent variable. The findings are consistent with the results for the dependent variable successful exit.

\section{Summary and conclusion}

In this study, I investigate how legal framework quality is related to the performance of different types of worldwide venture capital investments. My main conclusion is that legal framework 
Table 8

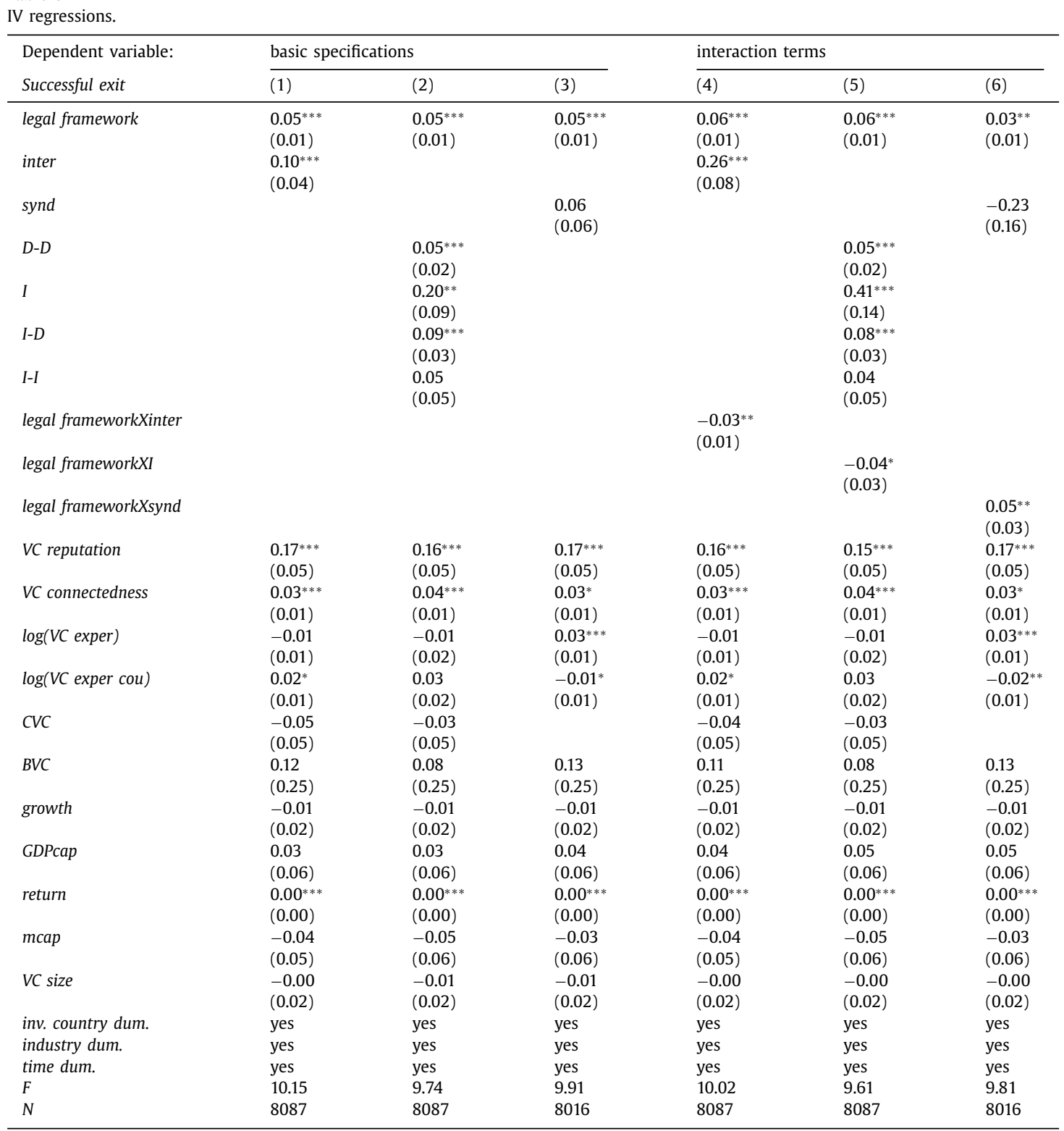

The table depicts the coefficients from IV models with successful exit as the dependent variable. Investments were made between January 1, 2003, and December 31, 2008, and exits took place by March 31, 2013. All variables and their sources are described in the appendix. The macroeconomic variables are from the VC investment year. The standard errors appear in brackets. ${ }^{*} p<.10,{ }^{* *} p<.05,{ }^{* * *} p<.01$.

quality in an investment country is linked to the success of such investments, but this effect varies with the deal type.

I find that international VCs seem to mitigate the problems that result from inefficient legal frameworks in the countries where they invest better than their domestic counterparts and thereby provide their portfolio companies with an additional value added, which has not been identified by the literature so far. My results suggest that this effect might be driven by at least two factors. First, international VCs tend to help their portfolio companies in international orientation by, for example, exiting these companies abroad. Non-local exit is more likely in countries with weak legal frameworks, which typically also suffer from a lack of local buyers. International VCs may help in finding foreign acquirers when local acquisition markets are weak. Second, international VCs have greater experience and reputation than domestic VCs, which might be helpful when dealing with inefficient legal frameworks. Moreover, my findings support the view that a sound legal frame- work improves the benefit-cost balance of syndication, while an inefficient legal framework may tend to increase costs in syndicated deals. Additional analyses with fine-grained measures of legal framework quality suggest that shareholder rights are more important than enforcement rights and accounting standards.

These results, which are robust to various alterations, add to the body of existing research on law and finance; moreover, they complement and expand the literature on venture capital internationalization, syndication, and exit performance.

Apart from that, my study invites further research into several issues whose investigation would benefit greatly from finding new sources of data to complement the existing commercial databases. First, additional sources of data from developing countries, in which legal institutions substantially differ from those in developed countries, would add to our understanding of the interplay between legal institutions and success in venture capital investments. Recently, researchers started to collect and use data 
Table 9

Additional robustness checks.

\begin{tabular}{|c|c|c|c|c|c|c|}
\hline \multirow[t]{2}{*}{ Dependent variable: } & \multicolumn{3}{|c|}{ Time to exit (hazard models) } & \multicolumn{3}{|c|}{ Size (OLS models) } \\
\hline & (1) & (2) & (3) & (4) & (5) & (6) \\
\hline legal framework & $\begin{array}{l}0.20^{* * *} \\
(0.06)\end{array}$ & $\begin{array}{l}0.18^{* * *} \\
(0.05)\end{array}$ & $\begin{array}{l}0.12^{* *} \\
(0.06)\end{array}$ & $\begin{array}{l}0.01 \\
(0.05)\end{array}$ & $\begin{array}{l}0.04 \\
(0.05)\end{array}$ & $\begin{array}{l}0.16^{* *} \\
(0.07)\end{array}$ \\
\hline inter & $\begin{array}{l}0.80^{* * * *} \\
(0.25)\end{array}$ & & & $\begin{array}{l}1.24^{* * *} \\
(0.29)\end{array}$ & & \\
\hline legal frameworkXinter & $\begin{array}{l}-0.11^{* *} \\
(0.04)\end{array}$ & & & $\begin{array}{l}-0.16^{* * *} \\
(0.06)\end{array}$ & & \\
\hline$I$ & & $\begin{array}{l}0.97^{* * *} \\
(0.32)\end{array}$ & & & $\begin{array}{l}1.61^{* * * *} \\
(0.33)\end{array}$ & \\
\hline legal frameworkXI & & $\begin{array}{l}-0.11^{*} \\
(0.06)\end{array}$ & & & $\begin{array}{l}-0.17^{* *} \\
(0.07)\end{array}$ & \\
\hline$D-D$ & & $\begin{array}{l}0.19^{* * * *} \\
(0.06)\end{array}$ & & & $\begin{array}{l}-0.61^{* * *} \\
(0.10)\end{array}$ & \\
\hline$I-D$ & & $\begin{array}{l}0.28^{* * * *} \\
(0.07)\end{array}$ & & & $\begin{array}{l}-0.23^{*} \\
(0.12)\end{array}$ & \\
\hline$I-I$ & & $\begin{array}{l}-0.05 \\
(0.16)\end{array}$ & & & $\begin{array}{l}-0.15 \\
(0.24)\end{array}$ & \\
\hline synd & & & $\begin{array}{l}-0.29 \\
(0.22)\end{array}$ & & & $\begin{array}{l}-1.17^{* * *} \\
(0.29)\end{array}$ \\
\hline legal frameworkXsynd & & & $\begin{array}{l}0.08^{* *} \\
(0.04)\end{array}$ & & & $\begin{array}{l}0.11^{*} \\
(0.06)\end{array}$ \\
\hline VC reputation & $\begin{array}{l}0.72^{* * * *} \\
(0.24)\end{array}$ & $\begin{array}{l}0.75^{* * *} \\
(0.23)\end{array}$ & $\begin{array}{l}0.75^{* * * *} \\
(0.24)\end{array}$ & $\begin{array}{l}1.95^{* * *} \\
(0.31)\end{array}$ & $\begin{array}{l}1.88^{* * * *} \\
(0.31)\end{array}$ & $\begin{array}{l}2.00^{* * * *} \\
(0.32)\end{array}$ \\
\hline VC connectedness & $\begin{array}{l}0.12^{*} \\
(0.07)\end{array}$ & $\begin{array}{l}0.12^{* *} \\
(0.06)\end{array}$ & $\begin{array}{l}0.10 \\
(0.07)\end{array}$ & $\begin{array}{l}-0.61^{* * *} \\
(0.08)\end{array}$ & $\begin{array}{l}-0.44^{* * *} \\
(0.08)\end{array}$ & $\begin{array}{l}-0.66^{* * *} \\
(0.08)\end{array}$ \\
\hline $\log (V C$ exper $)$ & $\begin{array}{l}0.05 \\
(0.04)\end{array}$ & $\begin{array}{l}0.05 \\
(0.04)\end{array}$ & $\begin{array}{l}0.12^{* * *} \\
(0.04)\end{array}$ & $\begin{array}{l}0.26^{* * * *} \\
(0.04)\end{array}$ & $\begin{array}{l}0.20^{* * * *} \\
(0.05)\end{array}$ & $\begin{array}{l}0.40^{* * * *} \\
(0.04)\end{array}$ \\
\hline $\log ($ VC exper cou $)$ & $\begin{array}{l}0.02 \\
(0.04)\end{array}$ & $\begin{array}{l}0.01 \\
(0.05)\end{array}$ & $\begin{array}{l}-0.06 \\
(0.04)\end{array}$ & $\begin{array}{l}-0.14^{* * * *} \\
(0.05)\end{array}$ & $\begin{array}{l}-0.06 \\
(0.05)\end{array}$ & $\begin{array}{l}-0.26^{* * * *} \\
(0.05)\end{array}$ \\
\hline$C V C$ & $\begin{array}{l}-0.15 \\
(0.22)\end{array}$ & $\begin{array}{l}-0.13 \\
(0.22)\end{array}$ & $\begin{array}{l}-0.12 \\
(0.22)\end{array}$ & $\begin{array}{l}-0.24 \\
(0.40)\end{array}$ & $\begin{array}{l}0.14 \\
(0.40)\end{array}$ & $\begin{array}{l}0.30 \\
(0.41)\end{array}$ \\
\hline$B V C$ & $\begin{array}{l}0.69 \\
(1.16)\end{array}$ & $\begin{array}{l}0.68 \\
(1.16)\end{array}$ & $\begin{array}{l}0.68 \\
(1.17)\end{array}$ & $\begin{array}{l}42,430 \\
(1.98)\end{array}$ & $\begin{array}{l}25,965 \\
(1.95)\end{array}$ & $\begin{array}{l}29,618 \\
(1.99)\end{array}$ \\
\hline growth & $\begin{array}{l}-0.02 \\
(0.09)\end{array}$ & $\begin{array}{l}-0.02 \\
(0.09)\end{array}$ & $\begin{array}{l}-0.01 \\
(0.09)\end{array}$ & $\begin{array}{l}-0.12 \\
(0.08)\end{array}$ & $\begin{array}{l}-0.15^{*} \\
(0.08)\end{array}$ & $\begin{array}{l}-0.03 \\
(0.10)\end{array}$ \\
\hline GDPcap & $\begin{array}{l}0.39^{*} \\
(0.22)\end{array}$ & $\begin{array}{l}0.43^{*} \\
(0.22)\end{array}$ & $\begin{array}{l}0.42^{*} \\
(0.22)\end{array}$ & $\begin{array}{l}-1.10^{* * *} \\
(0.21)\end{array}$ & $\begin{array}{l}-1.14^{* * *} \\
(0.21)\end{array}$ & $\begin{array}{l}-1.40^{* * * *} \\
(0.49)\end{array}$ \\
\hline return & $\begin{array}{l}0.01^{* * *} \\
(0.00)\end{array}$ & $\begin{array}{l}0.01^{* * *} \\
(0.00)\end{array}$ & $\begin{array}{l}0.01 * * * \\
(0.00)\end{array}$ & $\begin{array}{l}0.00 \\
(0.00)\end{array}$ & $\begin{array}{l}0.00 \\
(0.00)\end{array}$ & $\begin{array}{l}0.00 \\
(0.00)\end{array}$ \\
\hline mcap & $\begin{array}{l}-0.09 \\
(0.23)\end{array}$ & $\begin{array}{l}-0.10 \\
(0.23)\end{array}$ & $\begin{array}{l}-0.07 \\
(0.22)\end{array}$ & $\begin{array}{l}0.34 \\
(0.22)\end{array}$ & $\begin{array}{l}0.21 \\
(0.21)\end{array}$ & $\begin{array}{l}0.06 \\
(0.47)\end{array}$ \\
\hline VC size & $\begin{array}{l}0.07 \\
(0.09)\end{array}$ & $\begin{array}{l}0.07 \\
(0.09)\end{array}$ & $\begin{array}{l}0.06 \\
(0.09)\end{array}$ & $\begin{array}{l}0.24^{* *} \\
(0.11)\end{array}$ & $\begin{array}{l}0.28^{* * * *} \\
(0.11)\end{array}$ & $\begin{array}{l}0.25^{*} \\
(0.13)\end{array}$ \\
\hline inv. country dum. & yes & yes & yes & yes & yes & yes \\
\hline industry dum. & yes & yes & yes & yes & yes & yes \\
\hline time dum. & yes & yes & yes & yes & yes & yes \\
\hline chi2/F & 553.35 & 717.21 & 680.84 & 26.21 & 27.37 & 24.85 \\
\hline$N$ & 8092 & 8092 & 8092 & 3256 & 3256 & 3256 \\
\hline
\end{tabular}

Columns 1-3 depicts the hazard rates from Cox models with the dependent variable time to exit and columns 4-6 show the coefficients from linear (OLS) models with size as the dependent variable. Investments were made between January 1, 2003, and December 31, 2008, and exits took place by March 31, 2013. All variables and their sources are described in the appendix. The macroeconomic variables are from the VC investment year. The standard errors (clustered by investment country and year; see Petersen 2009 ) appear in brackets. ${ }^{*} p<.10,{ }^{* *} p<.05,{ }^{* * *} p<.01$

from Asian countries. It would be important to search for original data sources for investments in other regions, such as South America, Eastern Europe, or Africa. Second, hand-collected contractual data from different countries would help researchers examine in depth in which ways contracts vary between countries with different legal institutions and between different deal types, and how these differences are related to differences in investment success. Finally, an interesting avenue would be to investigate how VC effects differ under different political orientations and how these effects change with changing political conditions.

\section{Acknowledgments}

I appreciate the comments of Diego D'Adda, Elisabeth Berger, Monika Gehde-Trapp, Johannes Kolb, Andreas Kuckertz, Sophie Manigart, Miguel Meuleman, Kourosh Shafi, seminar participants in Ghent, Hohenheim and Trier, the participants at the Aidea Conference in Lecce 2013 and at the Entrepreneurial Finance Conference in Lyon 2016. I gratefully acknowledge access to data provided (i) by the DALAHO, University of Hohenheim and (ii) by the ZEW Mannheim. 
Appendix. Variable descriptions and sources

\begin{tabular}{|c|c|c|}
\hline Variable & Description & Source \\
\hline $\begin{array}{l}\text { Dependent variables } \\
\text { successful exit } \\
\text { (dummy) }\end{array}$ & $\begin{array}{l}\text { This variable equals } 1 \text { for successful exits, which are IPOs and M\&As by March 31, 2013. For investments that had not } \\
\text { been exited by March 31, 2013, the variable is set to } 0 \text {. }\end{array}$ & Zephyr \\
\hline $\begin{array}{l}\text { non-local exit } \\
\text { (dummy) }\end{array}$ & $\begin{array}{l}\text { This variable equals } 1 \text { for successful exits outside the investment country (acquired by foreigners or taken public } \\
\text { abroad) and } 0 \text { for successful exits within the investment country. Successful exits are IPOs and M\&As by March 31, } \\
2013 \text {. }\end{array}$ & Zephyr \\
\hline $\begin{array}{l}\text { time to exit } \\
\text { size }\end{array}$ & $\begin{array}{l}\text { Number of days between the investment and the successful exit (IPOs and M\&As by March 31, 2013). } \\
\text { (log) number of employees. }\end{array}$ & $\begin{array}{l}\text { Zephyr } \\
\text { Orbis }\end{array}$ \\
\hline \multicolumn{3}{|l|}{ Legal variables } \\
\hline legal framework & $\begin{array}{l}\text { Quality of the legal and regulatory framework in a country. A higher value indicates that the legal and regulatory } \\
\text { framework encourages more the competitiveness of enterprises. }\end{array}$ & $\begin{array}{l}\text { IMD World } \\
\text { Competitiveness } \\
\text { Yearbook }\end{array}$ \\
\hline legal_NHT & legal index = shareholder_NHT + enforcement_NHT + accounting_NHT (scale 0-3). A higher value is better. & $\begin{array}{l}\text { LaPorta et al. 1997, } \\
1998\end{array}$ \\
\hline shareholder_NHT & $\begin{array}{l}\text { Shareholder rights are aggregated on six indicator variables for each country: one share-one vote, proxy by mail, } \\
\text { cumulative voting, oppressed minorities mechanism, preemptive rights, and unblocked shares prior to meetings. The } \\
\text { sum is divided by six. A higher value is better. }\end{array}$ & $\begin{array}{l}\text { LaPorta et al. 1997, } \\
1998\end{array}$ \\
\hline enforcement_NHT & $\begin{array}{l}\text { Enforcement rights are aggregated of five law variables for each country (scale } 0-10 \text { ): efficiency of judicial system, rule } \\
\text { of law, corruption, risk of expropriation, and repudiation of contracts. The sum is divided by } 50 \text {. A higher value is } \\
\text { better. }\end{array}$ & $\begin{array}{l}\text { LaPorta et al. 1997, } \\
1998\end{array}$ \\
\hline accounting_NHT & Accounting standards for each country (scale $0-100$ ) divided by 100 . A higher value is better. & $\begin{array}{l}\text { LaPorta et al. 1997, } \\
1998\end{array}$ \\
\hline \multicolumn{3}{|l|}{ Deal types } \\
\hline inter (dummy) & This variable equals 1 if at least one international VC finances the investment, 0 otherwise. & Zephyr \\
\hline synd (dummy) & This variable equals 1 if more than one VC finances the investment, 0 otherwise. & Zephyr \\
\hline D (dummy) & This variable equals 1 for standalone domestic investments, 0 otherwise. & Zephyr \\
\hline D-D (dummy) & This variable equals 1 for syndicated domestic investments, 0 otherwise. & Zephyr \\
\hline I (dummy) & This variable equals 1 for standalone international investments, 0 otherwise. & Zephyr \\
\hline I-D (dummy) & This variable equals 1 for investments syndicated between domestic and international VCs, 0 otherwise. & Zephyr \\
\hline I-I (dummy) & This variable equals 1 for investments syndicated between international VCs, 0 otherwise. & Zephyr \\
\hline \multicolumn{3}{|l|}{ VC variables } \\
\hline VC reputation & $\begin{array}{l}\text { VC reputation at the time of the investment, measured as a fraction of IPOs on total exits in the 3-year period } \\
\text { preceding the investment. }\end{array}$ & Zephyr \\
\hline VC connectedness & $\begin{array}{l}\text { VC connectedness at the time of the investment, measured as a fraction of syndicated deals on total deals in the } \\
\text { 3-year period preceding the investment. }\end{array}$ & Zephyr \\
\hline VC exper & $\begin{array}{l}\text { VC experience at the time of the investment, measured as a past deal count in the } 3 \text {-year period preceding the } \\
\text { investment. }\end{array}$ & Zephyr \\
\hline VC exper cou & $\begin{array}{l}\text { VC experience in the investment country at the time of the investment, measured as a past deal count in the } \\
\text { investment country in the } 3 \text {-year period preceding the investment. }\end{array}$ & Zephyr \\
\hline BVC & The variable equals one if a bank-based VC participates. & Zephyr \\
\hline CVC & The variable equals one if a corporate VC participates. & Zephyr \\
\hline \multicolumn{3}{|c|}{ Country variables (annual basis) } \\
\hline growth & Expected real economic growth in the next 3-5 years in percent. & Datastream \\
\hline GDPcap & Country GDP per capita in USD. & Datastream \\
\hline return & Country stock market return in percent. & Datastream \\
\hline mcap & Country stock market capitalization over GDP. & $\begin{array}{l}\text { World Development } \\
\text { Indicators }\end{array}$ \\
\hline VC size & Size of the domestic venture capital industry in a country: number of active domestic VCs per million inhabitants. & Zephyr, Worldbank \\
\hline MA_hightech & Size of the domestic M\&A market in high-tech industries: Number of high-tech M\&As in the country/1000. & Zephyr \\
\hline IPO_hightech & Size of the domestic IPO market in high-tech industries: Number of high-tech IPOs in the country/1000. & Zephyr \\
\hline MA_all & Size of the domestic M\&A market: Number of M\&As in the country/1000. & Zephyr \\
\hline IPO_all & Size of the domestic IPO market: Number of IPOs in the country/1000. & Zephyr \\
\hline
\end{tabular}

\section{References}

Admati, A.R., Pfleiderer, P., 1994. Robust financial contracting and the role of venture capitalists. J. Finance 49 (2), 371-402.

Aizenman, J., Kendall, J., 2012. The internationalization of venture capital. J. Econ. Stud. 39 (5), 455-511.

Armour, J., Cumming, D.J., 2006. The Legislative Road to Silicon Valley. Oxford Economic Papers, pp. 596-635.

Bachmann, R., Schindele, I.. Theft and syndication in venture capital finance.

Balcarcel, A., Hertzel, M.G., Lindsey, L.A.. Contracting frictions and cross-border capital flows: evidence from venture capital.

Bertoni, F., Groh, A.P., 2014. Cross-border investments and venture capital exits in Europe. Corporate Governance: Int. Rev. 22, 84-99.

Beuselinck, C., Deloof, M., Manigart, S., 2009. Private equity involvement and earnings quality. J. Bus. Finance Accounting 36, 587-615.

Biais, B., Perotti, E., 2008. Entrepreneurs and new ideas. Rand J. Econ. 39 (4), $1105-1125$
Blind, K., 2012. The influence of regulations on innovation: a quantitative assessment for OECD countries. Res. Policy 41 (2), 391-400.

Bloom, N., Sadun, R., Van Reenen, J., 2009. Do Private Equity-Owned Firms have Better Management Practices? Centre for Economic Performance occasional papers, CEPOP24.

Brander, J., R., Amit, Antweiler, W., 2002. Venture capital syndication: improved venture selection versus value-added hypothesis. J. Econ. Manage. Strategy 11 (3), $423-452$.

Bygrave, W.D., 1987. Syndicated investments by venture capital firms: a networking perspective. J. Bus. Venturing 2, 139-154.

Casamatta, C., Haritchabalet, C., 2007. Experience, screening and syndication in venture capital investments. J. Financ. Intermediation 16 (3), 368-398.

Cestone, G., Lerner, J., White, L., 2007. The Design of Syndicates in Venture Capital Working Paper. doi:10.2139/ssrn.967310.

Chemmanur, T.J., Hull, T., Krishnan, K., 2016. Do local and international venture capitalists play well together? The complementarity of local and international venture capitalists. J. Bus. Venturing 31, 573-594. 
Choi, S.J., 2002. Law, finance and path dependence: developing strong securities markets. Texas Law Rev. 1657, 1660-1695.

Cumming, D.J., 2008. Contracts and exits in venture capital finance. Rev. Financ. Stud. 21 (5), 1947-1982.

Cumming, D.J., Fleming, G., Schwienbacher, A., 2006. Legality and venture capital exits. J. Corporate Finance 12 (2), 214-245.

Cumming, D.J., Fleming, G., Schwienbacher, A., 2009. Corporate relocation in venture capital finance. Entrepreneurship Theory Pract. 33, 1121-1155.

Cumming, D.J., Johan, S.A., 2006. Is it the law or the lawyers? Investment fund covenants across countries. Eur. Financ. Manage. 12, 553-574.

Cumming, D.J., Johan, S.A., 2008. Preplanned exit strategies in venture capital. Eur. Econ. Rev. 52 (7), 1209-1241.

Cumming, D.J., Johan, S.A., 2009. Legality and fund manager compensation. Venture Capital: Int. J. Entrepreneurial Finance 11, 23-54.

Cumming, D.J., Johan, S., Zhang, M., 2014. The economic impact of entrepreneurship: comparing international datasets. Corporate Governance: Int. Rev. 22 (2), $162-178$.

Cumming, D.J., Knill, A., 2012. Disclosure, venture capital and entrepreneurial spawning. J. Int. Bus. Stud. 43 (6), 563-590.

Cumming, D.J., Knill, A., Syvrud, K., 2016. Do international investors enhance private firm value? Evidence from venture capital. J. Int. Bus. Stud. 47 (3), 347-373.

Cumming, D.J., Schmidt, D., Walz, U., 2010. Legality and venture capital governance around the world. J. Bus. Venturing 25 (1), 54-72.

Cumming, D.J., Walz, U., 2010. Private equity returns and disclosure around the world. J. Int. Bus. Stud. 41, 727-754.

Dai, N., Jo, H., Kassicieh, S.K., 2012. Cross-border venture capital investments in Asia: selection and exit performance. J. Bus. Venturing 27 (6), 666-684.

Das, S., Jo, H., Kim, Y., 2011. Polishing diamonds in the rough: the sources of syndicated venture performance. J. Financ. Intermediation 20 (2), 199-230.

Demiroglu, C., James, C.M., 2010. The role of private equity group reputation in buyout financing. J. Financ. Econ. 96 (2), 306-330.

Esty, B.C., Megginson, W.L., 2003. Creditor rights, enforcement, and debt ownership structure: evidence from the global syndicated loan market. J. Financ. Quant. Anal. 38, 37-59.

Fluck, Z., Garrison, K., Myers, S., 2005. Venture Capital Contracting and Syndication: An Experiment in Computational Corporate Finance NBER Working Paper, No. 11624.

Giot, P., Schwienbacher, A., 2007. IPOs, trade sales and liquidations: Modelling venture capital exits using survival analysis. Journal of Banking \& Finance 679-702.

Gompers, P., Lerner, J., 1999. The Venture Capital Cycle. MIT Press, Cambridge.

Gompers, P., Lerner, J., 1996. The use of covenants: an empirical analysis of venture partnership agreements. J. Law Econ. 39 (2), 463-498.

Groh, A.P., von Liechtenstein, H., Lieser, K., 2010. The European venture capital and private equity country attractiveness indices. J. Corporate Finance 16, 205-224.

Hochberg, Y., Ljungqvist, A., Lu, Y., 2007. Whom you know matters: venture capital networks and investment performance. J. Finance 62, 251-301.

Hopp, C., Rieder, F., 2011. What drives venture capital syndication? Appl. Econ. 43 (23), 3089-3102.

Hsu, D., 2004. What do entrepreneurs pay for venture capital affiliation? J. Finance 59, 1805-1844.

Humphery-Jenner, M., Suchard, J.-A., 2013a. Foreign VCs and venture success: evidence from China. J. Corporate Finance 21, 16-35.

Humphery-Jenner, M., Suchard, J.-A., 2013b. Foreign venture capitalists and the internationalization of entrepreneurial companies: evidence from China (2013). J. Int. Bus. Stud. 44 (6), 607-621.
Kaplan, S.N., Strömberg, P., 2003. Financial contracting theory meets the real world: an empirical analysis of venture capital contracts. Rev. Econ. Stud. 70 (2), 281-315.

Klapper, L.F., Love, I., 2002. Corporate Governance, Investor Protection and Performance in Emerging Markets The World Bank Working Paper.

La Porta, R., Lopez-de-Silanes, F., Shleifer, A., Vishny, R., 1997. Legal determinants of external finance. J. Finance 52, 1131-1150.

La Porta, R., Lopez-de-Silanes, F., Shleifer, A., Vishny, R., 1998. Law and finance. J. Polit. Econ. 106, 1113-1155.

La Porta, R., Lopez-de-Silanes, F., Shleifer, A., Vishny, R., 2000. Agency problems and dividend policies around the world. J. Finance 55, 1-34.

Lerner, J., 1994. The syndication of venture capital investments. Financ. Manage. 23 $16-27$.

Lerner, J., Schoar, A., 2005. Does legal enforcement affect financial transactions? The contractual channel in private equity. Q. J. Econ. 120, 223-246.

Manigart, S., Lockett, A., Meuleman, M., Wright, M., Landström, H., Bruining, H., Desbrières, P., Hommel, U., 2006. Venture capitalists' decision to syndicate. Entrepreneurship Theory Pract. 30, 131-153.

Metrick, A., Yasuda, A., 2010. The economics of private equity funds. Rev. Financ. Stud. 23, 2303-2341.

Metrick, A., Yasuda, A., 2011. Venture capital and other private equity: a survey. Eur. Financ. Manage. 17 (4), 619-654.

Michaely, R., Roberts, M.R., 2012. Corporate dividend policies: lessons from private firms. Rev. Financ. Stud. 25 (3), 711-746.

Nahata, R., 2008. Venture capital reputation and investment performance. J. Financ. Econ. 90 (2), 127-151.

Nahata, R., Hazarika, S., Tandon, K., 2014. Success in global venture capital investing: do institutional and cultural differences matter? J. Financ. Quant. Anal. 49, 1039-1070.

Nicoletti, G., Pryor, F.L., 2007. Subjective and objective measures of governmental regulations in OECD nations. J. Econ. Behav. Org. 59, 433-449.

Norton, E.C., Wang, H., Ai, C., 2004. Computing interaction effects and standard errors in logit and probit models. Stata J. 4, 154-167.

Petersen, M., 2009. Estimating standard errors in finance panel data sets: comparing approaches. Rev. Financ. Stud. 22, 435-480.

Pichler, P., Wilhelm, W., 2001. A theory of the syndicate: form follows function. J. Finance 56 (6), 2237-2264.

Sahlman, W.A., 1990. The structure and governance of venture-capital organizations. J. Financ. Econ. 27 (2), 473-521.

Schertler, A., Tykvová, T., 2012. What lures cross-border venture capital inflows. J. Int. Money Finance 31 (6), 1777-1799.

Sorensen, M., 2007. How smart is smart money? An empirical two-sided matching model of venture capital. J. Finance 62, 2725-2762.

Tian, X., 2012. The role of venture capital syndication in value creation for entrepreneurial firms. Rev. Finance 16 (1), 245-283.

Tykvová, T., Schertler, A., 2014. Does syndication with local venture capitalists moderate the effects of geographical and institutional distance? J. Int. Manage. 20 (4), 406-420.

Wilson, R., 1968. The theory of syndicates. Econometrica 36, 119-132.

Wooldridge (2010). Econometric Analysis of Cross Section and Panel Data, second ed., The MIT Press.

Wright, M., Lockett, A., 2003. The structure and management of alliances: syndication in the venture capital industry. J. Manage. Stud. 40 (8), 2073-2102.

Zaheer, S., 1995. Overcoming the liability of foreignness. Acad. Manage. J. 38 (2), 341-363. 